\title{
El renegado de Jerusalén: la lucha contra el infiel y las relaciones hispano-francesas de comienzos del siglo XVII ${ }^{1}$
}

\author{
Raquel Sánchez Jiménez \\ Universidad de Valladolid \\ sraquel.raquel9@gmail.com
}

Recepción: 15/03/2021, Aceptación: 07/07/2021, Publicación: 22/12/2021

\begin{abstract}
Resumen
En el presente artículo acometemos el estudio de una comedia inédita tradicionalmente atribuida al célebre dramaturgo barroco español Luis Vélez de Guevara y titulada El renegado de Jerusalén, poco conocida debido a su conservación en un manuscrito de difícil lectura. Este drama histórico escenifica la batalla de Hattin (3-4 de julio de 1187), predecesora de la Tercera Cruzada (1187-1192), destacando el pacto que el conde Raimundo III de Trípoli contrajo con el sultán Saladino contra Guido de Lusignan, rey de Jerusalén junto a su esposa Sibila. En las próximas páginas, documentaremos la presencia del texto en catálogos y obras de referencia, ofreceremos una descripción física del manuscrito que la contiene y resumiremos su argumento. Además, analizaremos sus fuentes literarias e históricas, propondremos un período temporal probable para su escritura y estudiaremos sus peculiaridades genéricas con la finalidad de ofrecer una apropiada interpretación de su sentido histórico-político, vinculado a su elaborada capacidad referencial y propagandística.
\end{abstract}

Palabras clave

Luis Vélez de Guevara; El renegado de Jerusalén; Tercera Cruzada; Contrarreforma; pacto hispano-francés; Siglo de Oro; drama histórico barroco; comedia de moros y cristianos; comedia morisca.

1. Este artículo se enmarca dentro del Proyecto $\mathrm{I}+\mathrm{D}+\mathrm{i}$ del Ministerio de Ciencia e Innovación CLEMIT. Base de datos integrada del teatro clásico español. Segunda fase (PID2019-104045GB-C52). 


\begin{abstract}
English Title. El renegado de Jerusalén: the fight against the infidel and the HispanicFrench relations in the early $17 \mathrm{~h}$ Century.

This paper examines an unpublished theatre piece conventionally attributed to the famous Spanish Baroque playwright Luis Vélez de Guevara and titled El renegado de Jerusalén, little known of due to its preservation in a difficult to read manuscript. This historical drama depicts the battle of Hattin (3-4 July 1187), which led to the Third Crusade (11871192), emphasizing the agreement between Count Raymond III of Tripoli and Sultan Saladin against Guy of Lusignan, King of Jerusalem with his wife Sibylla. This research documents the play's presence in catalogs and reference works, offers a description of the manuscript that contains it and summarizes its plot. In addition, its literary and historical sources are analyzed, a probable time period for its writing is proposed and its generic peculiarities are discussed in order to offer an suitable interpretation of its historical-political meaning, linked to its complex referential and propaganda potential.
\end{abstract}

\title{
Keywords
}

Luis Vélez de Guevara; El renegado de Jerusalén; Third Crusade; Counter Reformation; Franco-Spanish pact; Spanish Golden Age; Baroque historical drama; Moors and Christians' drama; Moorish drama.

\section{Presencia de El renegado de Jerusalén en catálogos y obras de referencia. Descripción física del manuscrito}

El texto de El renegado de Jerusalén nos ha llegado a través de un único testimonio, un manuscrito que la Biblioteca Nacional de España alberga bajo la signatura MSS/14.968. En ella también pueden consultarse dos reproducciones digitales del texto —MSS.MICRO/570 y MSS.MICRO/12091—. Su presencia en catálogos es, por otra parte, exigua: Medel no la recoge en su Índice general alfabético, ${ }^{2}$ y no será hasta 1860 cuando una obra de referencia proporcione información sobre el

2. Medel del Castillo (1735). 
drama. Se trata del Catálogo bibliográfico y biográfico de La Barrera, que señala de modo prolijo la existencia de esta composición inédita y su autoría, que adjudica a Luis Vélez de Guevara, ${ }^{3}$ así como su procedencia de la biblioteca de don Agustín Durán. ${ }^{4}$ También recoge la noticia de la escenificación de una comedia titulada Conquista de Jerusalén, llevada a las tablas en el cuarto de la Reina a finales de 1622 o comienzos de $1623 .{ }^{5}$ Este título probablemente se refiera a La conquista de Jerusalén por Godofre de Bullón, ${ }^{6}$ atribuida a Cervantes y compuesta, aproximadamente, entre 1581 y $1585 .^{7}$ Paz y Meliá, al dar cuenta de las piezas teatrales conservadas en el Departamento de Manuscritos de la Biblioteca Nacional, incluye El renegado repitiendo la atribución a dicho escritor. ${ }^{8}$

Ya a comienzos del siglo xx, Cotarelo proporcionaba la primera descripción física del documento, así como su signatura:?

65. Renegado (El) de Jerusalén.

Manuscrito núm. 14968 de la Biblioteca Nacional, en 45 hojas en 4. ${ }^{\circ}$; letra del siglo XVII, muy tosca. Empieza:

Comedia del renegado de Jerusalén, (de otra letra; pero también antigua:) luis belez. Figuras las siguientes: El duque Efrando. - Ramón, conde. - Guido, rey. - Sibila, reina. - Elisa, infanta. - Una criada. - Laura. - Cartabón, lacayo. - Saladino, rey moro. - Ferraguto, moro. - Galván, moro. - Celino, moro. - Una sombra. - Un ángel. - Marcelo, caballero.

Acaba diciendo:

EFrando. Y aquel poeta que estriba

en que nuestra opinión viva,

dio fin al principio en quien

ganó honor Jerusalén:

otro el fin adverso escriba.

"Esta comedia es de Sebastián Ruiz, vecino del lugar del Carpio; por si se perdiere. - Sebastián Ruiz”.

3. Barrera (1860: 466, 577).

4. Barrera (1860: 466).

5. Barrera (1860: 537).

6. Esta no debe confundirse con la Jerusalén conquistada por Gofredo de Bullón de Vicente Rodríguez de Arellano, de la cual la biblioteca de Menéndez Pelayo alberga una copia. Cf. Vega GarcíaLuengos, Fernández Lera, Rey Sayagués (2001: 696-697, nota 2191).

7. Arata, en sus trabajos y en su edición a través de los cuales dio a conocer el texto de La conquista de Jerusalén, así como su atribución cervantina, sus características métricas y poéticas y diversas cuestiones en torno a su transmisión, proponía este lapso temporal como el más probable para su composición (Arata 2002a: 31-34, 2002b: 127). No obstante, el hispanista fijaba como término ad quem junio de 1586 a la luz de determinados aspectos relativos a uno de los testimonios de la comedia (Arata 2002a: 34, n. 12, n. 12, 2002b: 134-135). Brioso, en su edición crítica de la pieza, maneja este mismo margen cronológico, si bien sitúa el cierre del paréntesis cronológico en 1585 o principios de 1586, antes de la primavera de dicho año (Brioso 2009: 108, 110).

8. Paz y Meliá (1899: 714).

9. Cotarelo (1917: 415). 
Una edición de 1934 del ya citado Catálogo de Paz y Melia se hace eco de los datos proporcionados por Cotarelo con una pequeña variación: el nombre del copista del manuscrito, a quien llama Sebastián Fernández en lugar de Sebastián Ruiz. ${ }^{10}$ Esta divergencia entre ambos investigadores posiblemente se deba a la tosquedad de la escritura ${ }^{11}$ comentada por Cotarelo, dado que resulta complicado discernir qué rezan la nota y la firma que siguen al fin de la comedia:

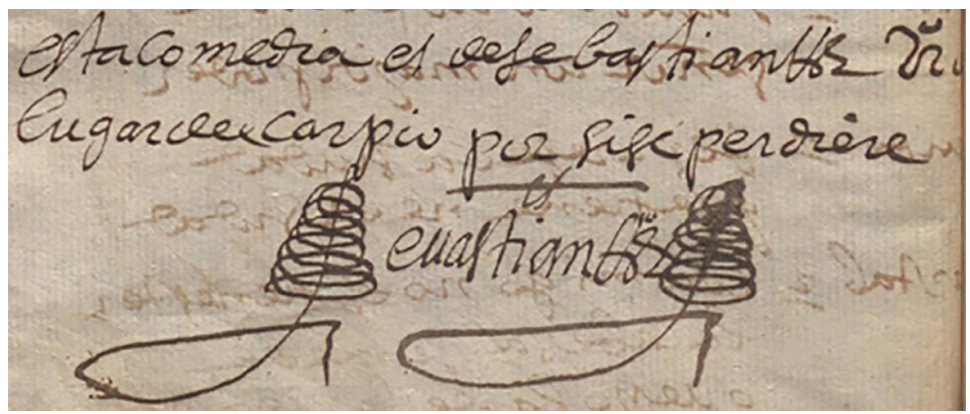

Figura 1: signatura del autor de la copia del texto dramático (f. 45v).

La monografía de Spencer y Schevill sobre Vélez de Guevara dedica su número 57 al texto que nos ocupa. ${ }^{12}$ Los investigadores apuntan la presencia del manuscrito en la Biblioteca Nacional, además de proporcionar un breve resumen de su argumento, una relación de los acontecimientos históricos en los cuales se sustenta y una propuesta de fuentes de El Renegado. También Urzaiz incluye el drama en su Catálogo de autores teatrales del siglo XVII, donde lo recoge en el apartado de obras atribuidas a este poeta indicando su ubicación en la Biblioteca Nacional y su correspondiente signatura. ${ }^{13}$

Por lo que respecta a posibles escenificaciones de esta composición, no hemos encontrado datos sobre este aspecto más allá de noticias de representaciones de piezas con títulos similares, como la relativa a la cervantina La conquista de Jerusalén por Godofre de Bullón antes mencionada, o la información que Schack proporciona acerca de una comedia titulada Jerusalén destruida, llevada a las tablas por las compañías de Damián y de Agustín Manuel entre el 25 y el 28 de

10. Paz y Meliá (1934: 474).

11. Al igual que Cotarelo y que Greer en la correspondiente ficha de Manos ("Renegado [El] de Jerusalén"), situamos cronológicamente la caligrafía en el siglo xvII.

12. Cf. Spencer y Schevill (1937: 239-242).

13. Urzaiz (2002: 705). 
abril de 1687 en el Palacio del Buen Retiro para la familia real. ${ }^{14}$ Posiblemente se trate de Los desagravios de Cristo, y Jerusalén destruida por Tito y Vespasiano, de Álvaro Cubillo de Aragón, que Urzaiz recoge señalando, además de su presencia en la Biblioteca Nacional y sus impresiones, otra escenificación de 1686 por la compañía de Manuel de Mosquera. ${ }^{15}$

En cuanto a la descripción física del manuscrito, podemos añadir algunas informaciones a las proporcionadas por Cotarelo. Greer, en la plataforma $M a-$ nos, corrige el número total de hojas, que el primero cifraba en 45, para afirmar que son $47 .{ }^{16}$ Nuestro examen del documento arroja una suma de 48 . El tomo presenta, además, dos hojas de guarda y un folio sin texto tanto en su parte anterior como en la posterior. El que precede al texto dramático contiene unas inscripciones en tinta procedentes de una mano distinta a la que ha copiado este último que dicen lo siguiente:

\section{MS. A. O. Ynedito | Renegado de Jerusalen | Velez de Guevara}

También figuran otras anotaciones a lápiz que parecen escritas por una mano diferente: "UV-451", y el número 16, que se sitúa en la parte central del folio. Su autor es, probablemente, el responsable de la numeración, también a lápiz, de los folios 46, 47 y 48: dado que la transcripción de la comedia abarca desde el 1 al 45, solo estos han sido foliados por una mano que estimamos coincidente con la del copista. Idénticas características presentan dos inscripciones situadas en los folios 3r y 20r que reproducen la signatura correspondiente al documento en la Biblioteca Nacional.

El drama finaliza en el folio $45 \mathrm{v}$, que presenta la signatura y unas rúbricas del amanuense. A la firma le precede la siguiente nota, escrita por el responsable de la reproducción de la pieza, cuyo apellido Greer también apunta como "Fernández": ${ }^{17}$ "Esta comedia es de Sebastián [ę?] lugar del Carpio por si se perdiere" (sic). El folio 46v presenta un listado invertido con trece nombres, que también recoge Manos. ${ }^{18}$ De todos ellos, únicamente hemos encontrado, en el $D I C A T$, una coincidencia con un cómico: se trata de Cristóbal Pérez, actor que figura en una nómina de personajes de la compañía teatral de Félix Pascual y

14. Schack (1887: 135). Sin embargo, en el DICAT de Ferrer Valls et al. (2008) se afirma que esta escenificación fue llevada a cabo por la compañía de Simón Aguado, de la cual también se documenta otra representación de la misma pieza fechada a 26 de junio del mismo año en el Salón Dorado del Alcázar.

15. Urzaiz (2002: 275). El DICAT, además de esta misma información y de las reseñadas en la nota precedente, proporciona otras relativas a escenificaciones de Los desagravios de Cristo realizadas por hasta una decena de compañías, la mayoría acontecidas en la ciudad de Valladolid. Cf. Ferrer Valls et al. (2008).

16. $C f$. Greer ("Renegado [El] de Jerusalén").

17. Greer ("Renegado [El] de Jerusalén").

18. Greer ("Renegado [El] de Jerusalén"). 
Agustín Manuel en una actuación correspondiente al Corpus de Madrid de 1671. ${ }^{19}$ Consideramos probable que se trate de una concurrencia nominal y que, como señala Greer, la lista contenga los nombres de vecinos de El Carpio, la localidad del copista, que a lo sumo podrían haber participado en una escenificación local. El documento, no obstante, no presenta señales de haber sido empleado para tal propósito. ${ }^{20} \mathrm{El}$ folio 47 , además, contiene el título de la comedia escrito con tinta; y el 48 , dos anotaciones más que no comparten autor entre sí: "Luis Velez" y "Sevastian" (sic). Asimismo, el ejemplar no presenta censura ni ninguna otra señal de haber pasado por un proceso censor.

Otro rasgo destacable del manuscrito es la apariencia del folio 1 , al cual le ha sido arrancada una porción en la parte inferior. Esto hace que el ex libris que indica su procedencia se encuentre dividido, con la parte superior estampada en el folio 1r; y la inferior, en el 2r. Este sello reza, en mayúsculas, "Librería del excmo. S. D. Ag. Duran” en su parte exterior y, entre dos filigranas, "B. N.”; en su interior puede leerse "Adquirida por el Gobierno en 1863". Además, el folio $2 r$ presenta algunas correcciones hechas por el propio copista que parecen responder a una mera subsanación de errores. Otra pequeña rectificación puede encontrarse en el folio 28r. El documento presenta un sello de la Biblioteca Nacional en los folios 1r, 3r, 11r, 16r, 27r, 39r, 45v y 46v.

\section{Argumento de la comedia}

La diégesis comienza en los instantes inmediatamente posteriores a la ceremonia de coronación de Guido como nuevo monarca de Jerusalén. Los nobles de la corte, encabezados por Efrando, lo aclaman y le besan la mano; y se da a conocer al público una importante ausencia: la del conde Ramón, quien se niega a reconocer la autoridad de Guido. En una nueva escena, encontramos a la reina Sibila dialogando con su hermana, la infanta Elisa, quien se queja de que Ramón amenaza con dar muerte a su enamorado, Efrando, si no le entrega su mano. Mientras Sibila la consuela, tiene lugar la primera aparición en escena del conde para pedirle a Guido que bendiga su unión con Elisa. El rey, molesto por las insolencias de su vasallo, le niega su petición con la excusa de que la dama ya tiene un compromiso, y ella lo repudia expresamente. El conde, frustrado por su fallido intento de alcanzar el trono y por su rechazo amoroso, manifiesta un profundo resentimiento contra su rey y contra su fe para la sorpresa de su criado, el gracioso Cartabón. Por otra parte, un equívoco entre Efrando y Elisa les hace creer que no se aman, a consecuencia de lo cual la joven decide retirarse a un jardín junto al mar para calmar sus ánimos. A continuación, arriban a la corte

19. Ferrer Valls et al. (2008).

20. Greer ("Renegado [El] de Jerusalén”). 
de Guido dos sarracenos, Ferraguto y Galván, embajadores de Saladino. El primero mantiene un airado intercambio de amenazas con el rey, mientras que el segundo manifiesta su intención de convertirse al cristianismo. Mientras el monarca jerosolimitano se dispone a bautizarlo, Ramón se alía con Ferraguto tras revelarle su deseo de renegar del cristianismo y de luchar contra el reino de Jerusalén. Asimismo, le pide ayuda para dar muerte a Elisa, pero el mahometano lo convence de secuestrarla y llevarla ante Saladino. En una nueva escena, ya al día siguiente, Sibila dialoga con su criada Laura sobre los hechos ocurridos haciéndole partícipe, además, de un mal sueño que ha tenido esa misma noche. Guido y Galván aparecen en escena con la noticia de la traición de Ramón y su marcha al palacio de Saladino. Este primer acto ${ }^{21}$ finaliza con la partida de Efrando hacia el jardín donde se había retirado su amada para prevenirle del peligro.

La segunda jornada, ${ }^{22}$ menos extensa que la anterior, arranca con la escena correspondiente al rapto de Elisa y Cartabón por Ramón, Ferraguto y "más moros". ${ }^{23}$ Pese a la resistencia de aquella, los captores los conducen a una galera y parten rumbo a los dominios de Saladino. Efrando arriba al lugar y encuentra a varios soldados muertos y a un caballero agonizante, Marcelo, que le relata lo ocurrido antes de fallecer. La acción se traslada así al palacio del sultán, donde este es despertado por una aparición, una "sombra o Muerte" que le revela ser el difunto Norandino y lo incita a entrar en combate con los cruzados e invadir Jerusalén. Seguidamente, llegan Ramón y Ferraguto con Elisa y Cartabón. El primero se presenta y tanto él como Ferraguto manifiestan sus ansias por atacar a los cristianos, pero el gobernante no muestra tanto interés, puesto que ha quedado prendado de la infanta. Al final del acto, Efrando comparece ante la fortaleza de Saladino para exigir el fin del cautiverio de su enamorada. Tras advertir al soberano del carácter traicionero del conde, anuncia un ataque de Jerusalén ante la resistencia de Ramón a liberar a la joven.

Da comienzo la tercera jornada ${ }^{24}$ mostrando a Ferraguto y Ramón enfrentados por forzar a Elisa. Este último, tras herir a Ferraguto, urde una trama para conseguir que Efrando sea aprisionado y convence a la joven de que firme un papel en blanco asegurando sus supuestas intenciones de retornar al bando y la fe cristianos. Pero, por el contrario, se servirá de esta signatura, que incluirá en una carta que enviará a Guido, para hacer creer al monarca que Efrando es un traidor. Ferraguto, para intentar seducir a la dama, le promete asesinar al sultán

21. Renegado (ff. 1r-18v). Las referencias a versos concretos de la comedia se realizarán indicando su posición en la parte recta $(\mathrm{r})$ o vuelta $(\mathrm{v})$ del correspondiente folio (f.) del manuscrito que se encuentra en la Biblioteca Nacional (MSS/14.968). Asimismo, nuestras remisiones a la obra constarán de su título abreviado, sin año, seguido de la indicación de los folios donde se ubique el texto citado.

22. Renegado (ff. 19r-31r).

23. Cf. Renegado (f. 19r, acotación).

24. Renegado (ff. 31v-45v). 
y ocupar su lugar. Ella, escandalizada, se dispone a delatarlo y él trata de asesinarla para impedirlo; pero Saladino, que se encontraba oculto escuchando la conversación, hace apresar y ejecutar al traidor y devuelve a la infanta su libertad. Se muestran entonces los preparativos para la batalla por parte de Ramón, quien envía a Cartabón a Jerusalén con el fatídico mensaje que causará el arresto de Efrando. Guido, en el bando cristiano, cae en el engaño y ordena que su vasallo sea apresado y que Galbán ocupe su lugar como general. Sin embargo, la llegada de Elisa disfrazada de hombre una vez comenzada la batalla descubre el equívoco y el rey decide liberarlo. Ante la inminente victoria cruzada, Ramón, herido, intenta huir del campo de batalla, pero una sombra - la Muerte-, junto con su propio ángel de la guarda, le impiden escapar. Galván, quien ya había amenazado al conde previamente, se topa con él y acaba con su vida mostrándole un crucifijo. Cartabón corta la cabeza del cadáver de su antiguo amo y le pone una mordaza. Guido ordena clavar la cabeza en una estaca y felicita a Galván por el triunfo cosechado. La obra termina tras bendecir Sibila el futuro matrimonio entre Efrando y la infanta.

\section{¿Un renegado en Jerusalén? La comedia entre la Poesía y la Historia}

Nuestra pieza plantea una escenificación de acontecimientos históricos notablemente libre en lo que se refiere a su fidelidad a ellos. Esta circunstancia responde a lo esperable de una ficcionalización realizada en los términos del subgénero áureo conocido como drama histórico, ampliamente estudiado y comentado en un nutrido corpus de trabajos a los cuales remitimos. ${ }^{25}$ Aunque este subgénero se sustenta sobre un pacto tácito entre dramaturgo y receptores en virtud del cual estos últimos "asumen que lo que se cuenta o representa, o parte de lo que se cuenta o representa, acaeció en el pasado, por más licencias que la poética autorizara a utilizar para su ornato", ${ }^{26}$ existe un amplio abanico de posibilidades en cuanto al distanciamiento de los motivos de la fábula respecto de lo acontecido. El autor de El renegado de Jerusalén no se limita a valerse de la Historia como un mero escenario en el cual situar una acción eminentemente ficticia; sin embargo, se encuentra más próxima a dicho extremo que al de una patente fidelidad a sus fuentes históricas al intepretar con una libertad notable los sucesos que condujeron a la Tercera Cruzada. Este es un factor directamente ligado a la relación entre el mensaje ideológico a transmitir y el episodio seleccionado para dicho fin. Así, las modificaciones de los hechos que veremos a continuación se encuentran cuidadosamente dispuestas en conexión con unos propósitos adoctrinadores y estéticos. Sin embargo, procede un breve recorrido histórico previo

25. González Cañal (2017), Oleza (1986, 2012, 2013), Martínez Aguilar (2000), Spang (1998). 26. Oleza (2013: 154, 2012: 71). 
a las transformaciones a las cuales nos venimos refiriendo para apreciar con mayor claridad el alcance de estas. Para su relación, seguimos tanto las crónicas consignadas en el epígrafe destinado a identificar las fuentes históricas del poeta como otras obras historiográficas de actualidad. ${ }^{27}$

El sexto monarca del reino franco de Jerusalén, al estar afectado de lepra desde la infancia, no contrajo matrimonio ni engendró descendencia. En previsión de su temprano fallecimiento y del problema dinástico parejo, la línea sucesoria se ligó a la descendencia de su hermana Sibila: ${ }^{28}$ Balduino V, fruto del primer casamiento de la joven con Guillermo de Montferrato, ${ }^{29}$ sería coronado co-príncipe en 1183.

Esta fue una estrategia de la facción más antigua de la nobleza jerosolimitana, ${ }^{30}$ con Raimundo III de Trípoli a la cabeza, para impedir que Guido, casado con Sibila en 1180 y regente del reino desde 1182, llegase a alcanzar el trono, puesto que no agradaba a la práctica totalidad de los cortesanos y, finalmente, tampoco al mismo rey, ${ }^{31}$ quien lo destituyó de su regencia en 1183. En 1185 fallecía este último, iniciándose el reinado de su sobrino con una nueva regencia de Raimundo. Balduino $\mathrm{V}$, sin embargo, tenía una salud aún más delicada que la de su predecesor y murió al año siguiente siendo aún un niño. Pese a que la Alta Corte había determinado que, ante el probable deceso del joven Balduino V, el papa, los reyes de Francia, los reyes de Inglaterra y el emperador germano se ocuparían de decidir su sucesión escogiendo entre Sibila y su medio hermana

27. Cf. Hosler (2019: 31-37, 209-210, 276), Arnold (The Chronicle, 145-151) - por ser este cronista mucho más conocido por su nombre que por su apellido, remitimos a él empleando el primero-, Rank (2015: 63-76), Möhring (2010: 73-106), Ultramar (caps. CXXVI-CLXIV, Libro Cuarto) — puesto que esta última obra no tiene una autoría segura, optamos por referenciarla indicando su título-

28. Para una mayor claridad expositiva, nos referiremos a los personajes históricos con los nombres que presentan en las fuentes propiamente históricas y, para aludir a sus respectivas versiones ficcionales en la comedia, mantendremos las designaciones que esta proporciona a cada uno de ellos. Así, en los casos de Guido, Sibila y Saladino no hay variaciones, puesto que así suelen ser llamados en las obras históricas. En un contexto histórico, denominamos a Efrando, Hunfredo; a Ramón, Raimundo; a Elisa, Isabel y a Norandino, Nur al-Din.

29. Este matrimonio resultaría particularmente breve, puesto que solo duró de 1176, cuando se concertó para proporcionar un linaje sucesor de Balduino IV lo más próximo posible a él, a 1177, año de fallecimiento de Guillermo.

30. También conocida como Alta Corte, Partido de los Nobles o Haute Cour de Jerusalén.

31. Al menos parte de las razones de este rechazo generalizado a Guido se encuentran en el afán de buena parte de la nobleza franca por mantener un control en las relaciones con Saladino que se permitiese períodos de tregua. Tal propósito fue alcanzado, pero quebrantado en 1186 por Reinaldo de Châtillon, uno de los principales aliados de Guido, cuando, tras sucesivos hostigamientos a los ejércitos del sultán, colmó su paciencia dirigiendo un ataque a una de sus caravanas que viajaba entre El Cairo y Damasco y que, además, transportaba a una hermana del rey sarraceno. Guido, que entonces ya ocupaba el trono de Jerusalén, optó por hacer oídos sordos a las exigencias de reparación hechas por Saladino abriendo así la puerta a la futura ofensiva. Cf. Möhring (2010: 74), Rank (2015: 67-68). 
Isabel, ${ }^{32}$ este acuerdo no fue respetado al dictaminar el patriarca Heraclio que Sibila heredaría el trono siempre y cuando se divorciase de Guido. Ella aceptó tal precepto bajo la garantía de poder escoger a su siguiente marido, circunstancia que aprovechó para, una vez coronada, volver a casarse con aquel. La Alta Corte trató de responder ante esta elusión de sus disposiciones designando a Isabel como reina de Jerusalén, pero Hunfredo IV de Torón, su marido, declinó esta opción, que habría desencadenado una guerra civil, y juró fidelidad a Guido. Al ver frustrados sus planes a través de artimañas un tanto irregulares, Raimundo se negó a reconocer a Guido y se refugió en su fortaleza en Tiberíades. ${ }^{33}$ Se iniciaba así una enemistad entre el nuevo monarca y el conde que se extendería durante, aproximadamente, ocho o nueve meses, entre agosto o septiembre de 1186 y mayo de 1187. Esta rivalidad motivó la alianza entre Saladino ${ }^{34}$ y Raimundo, quien, ante las amenazas de Guido contra su feudo tiberiano, decidió pactar con el sultán. Este, por su parte, había dado por rota la tregua con Jerusalén tras sucesivos ataques cruzados. Así, ambos acordaron que un contingente de soldados musulmanes se instalaría en Tiberíades para repeler futuros ataques del rey cristiano, lo cual, a su vez, proporcionaba a Saladino un pretexto para penetrar en territorio enemigo.

La amenazante presencia sarracena determinó el cese de las hostilidades entre Raimundo y Guido, convencido este último por la Alta Corte en vista de los inquietantes preparativos del adversario con el claro propósito de lanzar una ofensiva. El 2 de julio de 1187, Saladino organizó un ataque a la fortaleza tiberiana del tripolense y este, en una muestra de lealtad al monarca, ofreció la posibilidad de dejarla caer en manos enemigas para contrarrestar su estrategia de ataque; sin embargo, la escasa coordinación jerosolimitana determinó su derrota. Los dos días de combate correspondientes al 3 y 4 de julio de 1187 se saldaron con una aplastante victoria musulmana en la conocida como batalla de Hattin o de los Cuernos de Hattin. Durante la contienda fueron capturados numerosos y prominentes prisioneros, como Hunfredo y Reinaldo de Châtillon, quien fue ejecutado en venganza por sus constantes provocaciones. También Guido se vio cautivo en manos de Saladino y retenido por él en Damasco hasta verano del ańo siguiente. Junto con Hunfredo, el monarca fue de los pocos prisioneros que conservaron su vida: casi 200 templarios y hospitalarios fueron

32. Rank (2015: 75-76).

33. Ciudad a orillas del mar de Galilea construida en torno al año 20 d. C. por Herodes Antipas, quien la nombró en honor del emperador romano Tiberio. Fue ocupada por los francos en la Primera Cruzada y transformada en capital del Principado de Galilea, en ocasiones llamado Principado de Tiberia. Raimundo no solo era conde de Trípoli, donde tenía su fortaleza, sino también, por su matrimonio con Eschiva de Bures, príncipe de Galilea y de Tiberíades.

34. El nombre real de este personaje histórico es Șalāh ad-Dīn. A lo largo de este trabajo, sin embargo, nos referimos a él como Saladino al ser esta designación que recibe habitualmente en crónicas cristianas y textos históricos posteriores. 
decapitados. El 5 de julio, Tiberíades, que venía resistiendo el asedio, cayó en manos del sultán, quien entró en Acre, auténtico corazón del reino de Jerusalén, el 10 de julio, y recibió las llaves de la Ciudad Santa el 2 de octubre tras sitiarla desde el 20 de septiembre.

Durante los meses siguientes continuó el proceso de conquista islámica de diversos enclaves. El 29 de octubre de 1187, el papa Gregorio VIII ${ }^{35}$ llamaba a una nueva Cruzada en la cual tomaron parte algunos de los personajes que aparecen en nuestra comedia. Raimundo falleció poco después del desastre de Hattin y Guido, liberado por Saladino durante el estío de 1188, comenzó de inmediato a reunir un ejército con el cual asistir al sitio de Acre, que se prolongaría entre finales de agosto de 1189 y julio de 1191 con la presencia de figuras fundamentales en el bando cristiano como Felipe II de Francia, Ricardo Corazón de León, Federico Barbarroja, Guillermo II de Sicilia y Conrado I de Montferrato, hermano del difunto primer esposo de Sibila. Esta falleció en otońo de 1190, lo cual dejó a Guido en una precaria posición como monarca de Jerusalén al estar su posición en el trono determinada, precisamente, por su matrimonio con ella. Conrado, que no veía esta situación con buenos ojos, decidió casarse con Isabel, la heredera directa del trono, forzada a divorciarse de Hunfredo para tal efecto. Comenzaba así una prolongada disputa por el control del reino en la que Guido contó con el apoyo de Ricardo frente al cruzado italiano, respaldado por Felipe II. La cuestión se resolvió en 1192 en favor del segundo, quien, sin embargo, falleció ese mismo año. El pretérito gobernante de Jerusalén, tras jurar fidelidad al monarca inglés y comprarle Chipre, murió allí en 1194. Es particularmente destacable la fidelidad que recibió de Hunfredo, quien apoyó su candidatura al trono sobre la de Isabel, su propia esposa, tanto en 1186 como en 1190.

Sin perjuicio de los conflictos en otras regiones, el bloqueo de Acre que siguió a los fallidos propósitos de expulsar a los hombres de Saladino resultó fundamental para el progreso de la Tercera Cruzada en su conjunto. Después de casi dos años de resistencia contra los ejércitos cristianos claramente dificultada por el desabastecimiento y la lucha simultánea en otras plazas, se producía la rendición de las tropas musulmanas que se encontraban en la ciudad. El rey Ricardo había exigido al sultán el abono de un rescate y la entrega de las reliquias arrebatadas a cambio de todos los hombres que había capturado; sin embargo, ante su retraso en el pago, ordenó la ejecución de aproximadamente tres mil cautivos. El bando ayubí perdía en consecuencia medios, hombres y moral para continuar la guerra santa, a lo cual se unía la evidente incapacidad de su enemigo de reconquistar la urbe de Jerusalén y de defenderla posteriormente. Estas circunstancias fueron las principales impulsoras del armisticio (Tratado de Ramla) que Ricardo y Saladino cerraron el 2 de septiembre de 1192. Se pactó así

35. Sucesor de Urbano III, cuyo fallecimiento, se afirmaba, fue provocado por la noticia de la derrota de Hattin, que habría supuesto un duro golpe a su ya delicada salud. 
el alto el fuego y se estipuló el control cruzado de toda la franja costera entre Acre y Jaffa. Jerusalén permaneció en manos islámicas pese a las demandas del monarca inglés, aunque abierta a la peregrinación cristiana y con dos sacerdotes latinos en la famosa iglesia del Santo Sepulcro, mientras que los enclaves interiores de Lydda y Ramla se transformaron en un condominio. Además, Saladino se comprometió a devolver la reliquia de la Santa Cruz, sustraída tras la batalla de Hattin, pero esta permaneció finalmente en sus manos. Esta tregua no era vista por los implicados como el final de la guerra, sino como una pausa en la lucha con una duración prevista para tres años y ocho meses; no obstante, el sultán falleció solo medio año después de su firma, el 4 de marzo de 1193; y Ricardo cayó preso en manos de Leopoldo V, duque de Austria. Tras su liberación en 1194 transcurrió sus últimos cinco años de vida inmerso en conflictos relacionados con su reino en Inglaterra, sobre todo con Felipe II de Francia, por lo cual no pudo asistir a la Cuarta Cruzada (1192-1204).

La ficción que nos ocupa, como se aprecia en mayor detalle por contraste con los hechos históricos, los dramatiza de un modo manifiestamente libre. Las complejas circunstancias por las cuales Guido obtuvo el trono jerosolimitano no se representan en la pieza. En ella únicamente se encuentran las que pueden considerarse referencias muy sutiles a que es el matrimonio con Sibila lo que determina su acceso al trono, como un parlamento de Efrando al comienzo de la acción dramática, la cual arranca con un recién ungido Guido a quien vitorean los nobles de la Haute Cour: "besémosle la mano pues es justo / y se huelga la reina de su gusto", ${ }^{36}$ o las siguientes palabras de Elisa mientras se queja de la perfidia de Ramón: "como quiso don Ramón / por codicia de reinar / tu casamiento estorbar, / quiere estorbar mi afición". ${ }^{37}$ Por tanto, aunque la comedia incide en la circunstancia de que el conde se encuentra ausente en el momento en el cual el resto de cortesanos, con un papel prominente de Efrando, se encuentran presentando sus respetos al nuevo monarca, el autor de nuestro texto se cuida de omitir las razones que el histórico Raimundo de Trípoli adujo para no reconocerlo como tal.

Manteniéndonos en el terreno de las relaciones entre Poesía e Historia de $E l$ renegado, nos referiremos a un episodio de naturaleza evidentemente ficticia que, a su vez, tiene como referente un texto ficcional ${ }^{38} \mathrm{y}$ es presentado como un

36. Renegado (f. 1v).

37. Renegado (f. 4r).

38. En este contexto, empleamos el término "poético" como equivalente a "ficcional". Con ambas designaciones nos referimos a aquellos textos de naturaleza ficcional. Se trata de textos constructivos, que crean un universo de ficción o mundo ficcional al cual se orienta su referencia en contraposición a los textos descriptivos, cuyos términos aluden a elementos integrantes de la realidad fenoménica. Así, un motivo es ficcional —o poético— en función de su presencia en un mundo de ficción y con independencia de si existe o no en el mundo real. Para aludir a aquellos motivos que únicamente tienen presencia en el texto de ficción y que no se encuentran en la rea- 
factor de peso para el comienzo de las hostilidades entre el bando musulmán y el cristiano. Nos referimos a la espectacular aparición del espectro de Norandino ${ }^{39}$ ante Saladino mientras este duerme, ${ }^{40}$ motivo de procedencia lopesca. Si bien puede entenderse el descanso del sultán como una alusión metafórica a su armisticio con Balduino IV, consideramos que las referencias a esta circunstancia las constituyen tanto la mención directa al difunto rey que Guido introduce en su airada conversación con Ferraguto - "Si en tiempo quiso darla [embajada] Balduino, / ahora quiero yo no darte estrado, / siéntate en esa silla, sarraceno, / di tu embajada" - ${ }^{41}$ como la exigencia, en esta misma escena, que el embajador hace al monarca jerosolimitano de entregar determinadas plazas "antes que rompa [Saladino] de amistad las treguas". ${ }^{42}$ Por otra parte, las provocaciones por parte de la facción cruzada, como las de Reinaldo de Châtillon, son eludidas por la diégesis, que tampoco cuenta con la presencia de este último. Consideramos que estas exclusiones responden al propósito de presentar un panorama polarizado, con una clara superioridad moral de los cristianos sobre sus rivales, aspecto al cual también puede deberse la omisión de las intrigas palaciegas que precedieron a la coronación de Guido. Por tanto, la presencia de un fantasmal Norandino probablemente se vincula más con una voluntad de referenciar a Lope que a un interés propiamente histórico en vista de que la cuestión del alto al fuego carece de peso en la trama de la obra. De modo muy general, puede afirmarse que la relación entre Saladino y Nur al-Din fue, como mínimo, tensa. Durante el ascenso político-militar del primero, la confianza entre ambos fue desgastándose. Esta circunstancia se vio alimentada por el creciente poder de Egipto, donde Saladino era visir desde 1167 y, pocos años después, emir. El fallecimiento de Nur al-Din en 1174 permitió al ambicioso joven hacerse con numerosos territorios, de modo que en 1182 era seńor de todos los territorios no cruzados sirios y egipcios. Fue, asimismo, el primer gobernante islámico que rodeaba la totalidad del reino jerosolimitano con sus dominios, lo cual explica el

lidad, preferimos la denominación "ficticio". Cf. Sánchez Jiménez (2020: 3-30, 47-54, 69-90, 129 , nota 39).

39. Nur al-Din (1118-1174), también conocido como Norandino, fue uno de los personajes más relevantes del bando islámico en los años inmediatamente previos a la época que nos ocupa. Hijo del vasallo selyúcida Zengi, sucedió a su padre como emir de Alepo y se hizo con Damasco durante la Segunda Cruzada. Famoso entre sarracenos y cristianos por sus conquistas, trató de unificar Egipto y Siria bajo un solo mando con el objetivo de facilitar la invasión de territorios cruzados chocando en su propósito con Saladino, por entonces visir de Egipto. No llegó a producirse un combate entre ambos debido al fallecimiento de Nur al-Din por unas fiebres, tras lo cual Saladino se proclamó sultán de Egipto y Siria, cuya toma completó en 1182.

40. Cf. Renegado (f. 23v, acotación).

41. Renegado (f. $11 \mathrm{v})$.

42. Cf. Renegado (f. 12r). Ferraguto, en nombre de Saladino, reclama las plazas de Trebisonda, "Papilia" y Laodicea. Esta demanda del sultán tiene unas implicaciones que serán examinadas en detalle más adelante. 
deseo de algunos miembros de la Alta Corte cristiana de mantener, al menos, ciertos períodos de pausa en las hostilidades. ${ }^{43}$

También el romance entre Efrando y Elisa tiene un fundamento histórico: Hunfredo IV de Torón e Isabel de Jerusalén fueron casados por Balduino IV en 1183 y se divorciaron en 1190 para que Conrado de Montferrato accediese al trono a través de su matrimonio con la infanta. Esta fue una separación forzosa que pudo inspirar a nuestro poeta para concebir el episodio ficticio del secuestro por parte de Ramón y Ferraguto. Este motivo dramático manifiesta claras reminiscencias mitológicas a través de su evidente paralelismo con el rapto de Helena por Paris, desencadenante de la guerra de Troya. En relación con Efrando, es destacable que la comedia se hace eco de la lealtad del histórico Hunfredo a Guido con un matiz moralizante al presentarlo como el más sobresaliente entre los nobles de su corte en general $-\mathrm{y}$ con algunos rasgos heroicos que, sin embargo, quedan eclipsados por la perfidia de Ramón-, y entre los que lo vitorean en las primeras escenas en particular. ${ }^{44}$ Incide en este sentido la circunstancia de que la pieza comience y termine con sendos parlamentos correspondientes a este personaje. Por lo que respecta a Elisa, no se aprecia en la totalidad del texto ninguna referencia a la circunstancia de que Isabel de Jerusalén ascendería al trono del reino apenas tres años después de los acontecimientos históricos representados. No obstante, resulta llamativa la caracterización de su correspondiente versión ficcional como una joven fuerte, valiente y decidida, además de ferviente defensora de la cristiandad. Su personalidad firme, junto con su resistencia ante sus raptores al inicio de la segunda jornada, que la presenta "con una espada desnuda" ${ }^{45}$ así como la escena donde se viste de hombre para reunirse con los suyos una vez liberada por Saladino ${ }^{46}$ permiten categorizarla como el tipo femenino conocido como mujer varonil. El éxito de esta figura en la dramaturgia áurea no debe, sin embargo, ser confundido con una consideración más positiva de la que generalmente recibían las mujeres entonces ${ }^{47}$ bien patente en las palabras de la propia Elisa durante su defensa del ataque de Ramón y sus aliados musulmanes: "Teneos, cobardes villanos, / que soy noble aunque mujer". ${ }^{48}$ Lo mismo ha de tenerse en cuenta en lo relativo al disfraz varonil: la atribución a las mujeres de rasgos tradicionalmente entendidos como exclusivos de los varones, de forma interna o externa, tiene una

43. Cf. Rank (2015: 63-70), Möhrig (2010: 51-72).

44. Cf. Renegado (ff. 1r-2v).

45. Cf. Renegado (f. 19r, acotación).

46. Cf. Renegado (ff. $41 \mathrm{r}-41 \mathrm{v}$ ). Es destacable que la propia infanta hace una suerte de presentación del que será su atuendo en la escena anterior a la que la muestra vestida de varón: "El vestirme es necesario / de un vestido extraordinario, / solo por que tenga Guido / un soldado prevenido / en el campo del contrario", en Renegado (f. $37 \mathrm{v}$ ).

47. Cf. Sánchez Jiménez (2020: 163, 185-186, 193, 357-358, 396-397, 448-449, 502-505, 593 594), Ferrer Valls (2008: 27-30), Stroud (1983), Vitse (1978), McKendrick (1974).

48. Renegado (f. 19r). 
finalidad estética y dramática, de acuerdo con los efectos específicos que los autores persiguen para las diégesis de sus obras "con la intención de agradar al público y no tanto de reivindicar los derechos que se negaban a las mujeres de la época". ${ }^{4}$

Las modificaciones históricas más importantes se encuentran, pues, en lo tocante a la relación entre Raimundo de Trípoli y Saladino, así como al resultado de la contienda de Hattin. Dado que la caracterización extremadamente negativa de la versión ficcional del primero, el conde Ramón, responde a circunstancias ideológicas que serán estudiadas en la parte final de este trabajo, también nos ocuparemos de sus rasgos más destacables, en conexión con los de Ferraguto, en dicha sección. Por ahora, señalaremos que el intercambio del penoso desenlace de la batalla que incluyó, además del vencimiento, la captura de rehenes y el expolio de reliquias como la de la Santa Cruz, por una victoria cristiana es la solución que desde nuestra pieza se propone ante el problema, nada desdeñable, del tratamiento ficcional de una derrota histórica. Puede apreciarse, sin embargo, una sutil alusión a los funestos hechos que sacudieron al bando cruzado, como si de una represalia futura se tratase, en un parlamento de Galván: "Saladino ha de volver, / señor, con mayor poder". ${ }^{50}$ La elección de esta alternativa que altera sustancialmente la verdad histórica es, de hecho, proclamada en el parlamento de Efrando que cierra la acción dramática, dado que la modificación de acontecimientos pretéritos resulta perfectamente válida en el subgénero al que pertenece El renegado de Jerusalén: ${ }^{51}$

EFrando. Y aquel poeta que estriba

en que nuestra opinión viva

dio fin al principio en quien

ganó honor Jerusalén;

otro el fin adverso escriba. ${ }^{52}$

Por otra parte, la diégesis muestra al conde Ramón acudiendo a Saladino con el propósito de buscar su ayuda en su afán personal de venganza contra Guido. Este aspecto se aprecia a la perfección en la escena en la cual el renegado se presenta con Ferraguto en la corte del sultán para insistirle en la necesidad de atacar al reino cristiano mientras este manifiesta mayor interés en la belleza de Elisa que en la cuestión bélica ${ }^{53}$ pese a la incitante aparición de Norandino de la que acaba de ser testigo. Históricamente, el afán de Saladino por aliarse con Raimundo de Trípoli era muy superior al que manifiesta en el texto de ficción, pues fue él mismo, según relaciones más próximas cronológicamente a estos sucesos, quien propuso al

49. Rodríguez Campillo, Jiménez López, Bel Enguix (2011: 77).

50. Renegado (f. 45r).

51. Tal modificación de motivos históricos, de otra parte, también permite la disposición de materiales procedentes de otros subgéneros dramáticos, como estudiaremos en la última sección de nuestro trabajo.

52. Renegado (f. 45v). Destacado propio.

53. Cf. Renegado (ff. 24v-25v). 
conde una unión contra el monarca de Jerusalén. ${ }^{54}$ En general, El renegado proyecta una imagen favorable del gobernante musulmán, circunstancia que, más allá de cierta pretensión de mostrar tanto una dignidad supuestamente natural a la realeza como una superioridad moral sobre el antagonista de la fábula, también puede deberse a cierta influencia de las fuentes históricas sobre el drama. Los testimonios francos que se conservan sobre la persona de Saladino lo retratan como un hombre particularmente noble, cordial y honorable, ${ }^{55}$ lo cual algunos historiadores explican, en parte, como justificación de las graves pérdidas que les ocasionó:

Perder Jerusalén constituía, muy probablemente, un hecho imposible de tolerar. Por lo tanto, afirmar que el hombre que se había apoderado de ella tenía, por sí mismo, características sobrehumanas era una buena manera de conservar intacto el orgullo. ${ }^{56}$

La presentación específica de los acontecimientos históricos que acabamos de estudiar, pues, se orienta a una prioridad concreta, que es la de mostrar una representación intachable del reino franco de Jerusalén y de algunos de sus principales personajes. La caracterización de Raimundo como un traidor irredimible viene a desempeñar la misma función: por contraste con un antagonista totalmente aborrecible, se refuerza lo positivo de los cruzados, estrategia íntimamente vinculada al contexto sociopolítico de escritura del drama histórico que nos ocupa.

\section{Fuentes literarias e históricas}

El renegado de Jerusalén reúne múltiples manifestaciones de intertextualidad que contribuyen a enriquecer notablemente su capacidad referencial. Comenzaremos refiriéndonos a las obras literarias de las cuales se sirvió su autor.

Spencer y Schevill hipotetizaban en su monográfico que la pieza se había visto inspirada por La Jerusalén conquistada, poema épico de Lope de Vega. ${ }^{57}$ Esta composición, impresa por primera vez en $1609,{ }^{58}$ trata la Tercera Cruzada (1187-1192) centrándose en la figura del castellano Alfonso VIII — cuya intervención en el conflicto es ficticia- $\mathrm{e}$ introduciendo una igualmente ficticia reconquista de Jerusalén tras su caída en manos de Saladino. En este sentido, por tanto, presenta diferencias significativas con la Jerusalén liberada de Torquato Tasso (1567), que versaba sobre la Primera Cruzada. Nuestro poeta se vio influenciado, fundamentalmente, por el Libro Primero del texto lopesco, que trata los acontecimientos recogidos en El re-

54. Cf. Arnold (The Chronicle, 147), Ultramar (cap. CXXXII, Libro Cuarto).

55. Payne (2019: 263).

56. Rank (2015: 65). En términos muy similares se pronuncia González (1992: 85-86).

57. Spencer y Schevill (1937: 242) se refieren a la primera impresión del poema, que data de 1609 y que vio la luz en la famosa imprenta de Juan de la Cuesta bajo el título La Jerusalén conquistada, Epopeya trágica. De Lope Felis de Vega Carpio familiar del Santo Oficio de la Inquisición.

58. Carreño (2003: IX). 
negado de Jerusalén. Resultan particularmente llamativas las similitudes entre las representaciones que ambos literatos realizan del episodio de la aparición del fallecido Norandino ante Saladino para animarlo a atacar a los francos, paralelismos que documentan cómo el autor de nuestra comedia homenajea al Fénix en ella y disipan las posibles dudas respecto de su conocimiento del poema:

\section{El renegado de Jerusalén ${ }^{59}$}

Muer. ${ }^{61}$ Cobarde rey que en regalada cama pasas la noche y la mitad del día, recostado en los brazos de tu dama, muera aquí de temor tu cobardía. ¡Al arma, al arma, Saladino, cierra! Vuelve los ojos a la sangre clara de los hombres sin numerosa tierra a pesar tuyo, la espantosa espada suene en tu reino la espantosa guerra al compás de la trompa alborotada. ¡Al arma, ...!

SALAD.

Muer.

SALAD. ¿Quién eres? Sombra...

Muer. El difunto Norandino (Vase).

SALAD. ¡Aguarda, Muerte! ¿A mi valor te atreves, cuando no se me atreve el enemigo?

Los torpes labios en mi ausencia mueves, no saldrás de mis brazos sin castigo.

¡Vengan las armas, que vestirme quiero!

No de bizarro capellán bordado; de peto sí, y el espaldar de acero, con diamantes finísimos sembrados. ¡Tiembre de Saladino el mundo entero!

\section{Jerusalén conquistada ${ }^{60}$}

“[ [....] Que estás durmiendo sin temer

[tu daño,

taurocita cruel? ¿Cómo no miras, que infamas las cenizas de estas piras? [...]

Toma las armas, bárbaro persiano, toca a marchar, cobarde Saladino, vibra los rayos en la turca mano, serás del Asia Júpiter divino; yo soy la envidia del valor cristiano, la imagen soy del muerto Norandino, rey de Damasco, el que vencí la empresa que repite Antioquía y llora Edesa”.

Dijo, y con grito horrísono, temblando la cuadra, al paño la fantasma aplica, adonde Bruno Lusiñano alzando la espada que le vence significa; el eco por la sala resonando, la voz articulada testifica: que porque a la verdad la duda quite las últimas palabras le repite.

"Aguarda" — dice en sueños, y revuelve el pabellón con la siniestra mano; despierta el persa pero ve que envuelve la sombra en humo, el cuerpo asido [en vano;

apenas por el aire se disuelve cuando parece que el pendóncristiano ve levantar victoriosas voces terror de sus jenízaros feroces.

Ármase todo, y el arnés lucido de púrpura cubrió, bañada en oro...

Más allá de las coincidencias entre los extractos recién reproducidos, el efecto impactante y con notas tétricas de estas estrofas de la Jerusalén conquistada debió de calar hondo en la sensibilidad de nuestro dramaturgo, puesto que la

59. Renegado (ff. 23v-24r).

60. Vega (Obras completas, $\$ \$ 21,29-32$. Libro Primero).

61. Por razones de economía espacial, abreviamos "Muerte" con "Muer." y "Saladino" con "Salad.". 
sombra, abstracta representación de la muerte y de los difuntos, volverá a hacer una espectacular aparición al final del tercer acto.

El largo poema lopesco da cuenta en su Libro Primero de la caída del rey Guido en manos enemigas durante la batalla, de la victoria musulmana a cambio de su liberación y de la decapitación de Reinaldo de Châtillon, además de mostrar a un conde Remón (sic) aliado con Saladino en Hattin. Asimismo, el Fénix contrapone las figuras de Hunfredo y Raimundo, en una representación del bien frente al mal, de lo cristiano frente a lo gentil, que pudo inspirar a nuestro autor para su propia plasmación estética de la Historia:

Mas como tuvo [Cristo] a sus divinos lados
dos hombres, uno de los cuales tuvo
tal fe en los brazos de una cruz colgados
que asido de ellos en su cielo estuvo,
y el otro, a quien los cielos enlutados,
el sol, que de admirado se detuvo,
y las piedras que hablando no movieron,
así Herfrando y Remón con la cruz fueron.
Casado estaba Herfrando con Elisa,
hermana de Cristina generosa,
reina en Jerusalén que a la Fenisa
venció (sino en ser casta) en ser hermosa;
esta guardó la celestial divisa
de nuestra vida y redención dichosa,
pero el conde cruel tránsfuga fiero
volviose al Turco a quien sirvió primero. ${ }^{62}$

Finalmente, es posible advertir otra vía de influencia de esta obra épica sobre el texto que nos ocupa. En la composición de Lope, la princesa Ismenia recurre al disfraz varonil para ser confundida con su propio hermano, Dinodoro, y asistir a la Cruzada siguiendo a Alfonso VIII, de quien está enamorada. En el Libro Octavo de la Jerusalén conquistada, la dama consigue presentarse ante el rey castellano cuando este se encuentra cautivo. Circunstancias similares concurren en la tercera jornada de El renegado, donde Elisa se viste de hombre con la finalidad de llegar a salvo desde la corte de Saladino al bando jerosolimitano mientras tiene lugar el combate entre las tropas del sultán y las cristianas. Su llegada junto a Guido permitirá que Efrando recupere su libertad, perdida a causa de la artimańa de Ramón. En ambos casos, pues, encontramos una mujer que temporalmente adopta una apariencia masculina para introducirse en un entorno de hostilidades y poder comparecer ante un rey, así como un aprisionamiento en circunstancias injustas. Así, dada la elevada probabilidad de que el

62. Vega (Obras completas, $\$ \$ 97-98$. Libro Primero). 
autor de El renegado conociese bien el poema lopesco en el momento de su escritura a tenor de los múltiples aspectos que uno y otro tienen en común, incluyendo sus respectivos ámbitos de caracterización varonil, juzgamos posible que la escena de Ismenia vestida de hombre inspirase la análoga de Elisa en el drama.

De otra parte, el empleo del romance en nuestra comedia constituye una manifestación fundamental de la notable influencia que Lope ejerció sobre ella. Hemos contabilizado en el texto un total de 2187 versos de los cuales 300 se corresponden con dicho metro, de modo que este supone, aproximadamente, un $13,72 \%$ del total ${ }^{63}$ y se distribuye en tres pasajes que, además, incorporan sus respectivos estribillos. El primero de ellos, el más extenso, se localiza en el primer acto y consta de dos parlamentos, uno de Efrando y otro de Elisa, airados ambos por una confusión que les hace creer que no se corresponden en sus sentimientos amorosos. En los setenta y ocho versos recitados por el galán ${ }^{64}$ se repite una combinación de heptasílabo y endecasílabo, "Pero si estás casada, / celos te maten, pues con celos matas", cinco veces — la última de ellas introduce una modificación que no altera el número de sílabas: "Mas pues estás casada, / celos te maten, pues con celos matas" - . La furiosa respuesta de la infanta que les sigue intercala en dos ocasiones a lo largo de los cuarenta y ocho versos que la integran ${ }^{65}$ su propio estribillo, "ya tiene enemigo fiero, / celos te maten, pues con celos muero": se trata de un octosílabo seguido de un endecasílabo.

El segundo pasaje escrito en forma arromanzada se encuentra hacia el comienzo de la segunda jornada y, al igual que el anterior, consta de dos partes: comienza con la relación del rapto de Elisa por Ramón y sus aliados realizada por el moribundo caballero Marcelo ${ }^{66}$ y continúa con las afectadas palabras de Efrando declarando su propósito de partir en busca de su amada. ${ }^{67}$ En esta intervención del héroe encontramos cuatro veces a lo largo de sus cincuenta y cinco líneas un estribillo de dos versos, el primero pentasílabo y el segundo endecasílabo ("Elisa, aguarda, / darás lugar a que te siga el alma"), con una pequeńa variación en el último caso que transforma en octosílabo el pentasílabo inicial: "Elisa, detente, aguarda, / darás lugar a que te siga el alma".

La última porción en romance de todo el texto se ubica al final del segundo acto, ${ }^{68}$ en la escena que muestra a Efrando exigiendo ante la fortaleza de Saladino que la infanta sea puesta en libertad. Tanto el sultán como Ramón intercalan breves respuestas a las amenazas del cruzado que también presentan esta forma métrica. La jornada termina con una réplica del conde cuyo último octosílabo,

63. Estos datos se distribuyen como sigue: primer acto, $842 \mathrm{vv} ., 126$ de romance; segundo acto, 669 vv., 174 de romance; el tercer acto, con 676 versos, no presenta esta estrofa.

64. Renegado (ff. 8v-9v).

65. Renegado (ff. 10r-10v).

66. Renegado (ff. 22r-22v).

67. Renegado (ff. $22 \mathrm{v}-23 \mathrm{v}$ )

68. Renegado (ff. $29 \mathrm{v}-31 \mathrm{r}$ ). 
"fanfarrón cristiano, vete", ya ha enunciado con anterioridad; concretamente, diez líneas antes. Este constituye, pues, un estribillo unimembre.

Existen notables similitudes entre los pasajes que acabamos de señalar en primer y tercer lugar y la composición de juventud de Lope de Vega correspondiente a su ciclo de romances pastoriles de Belardo y Filis "Al pie de un roble escarchado". Tanto este como el fragmento romanceril de la primera jornada contienen la temática de los celos, así como la idea del castigo en proporción al mal de amores provocado y las quejas de los amantes expresadas a través del estribillo, que en el poema del Fénix consta de un único verso - "quien tal hace, que tal pague"-, característica esta última que también cumple el último pasaje en romance de El renegado. Así pues, existen indicios suficientes para estimar que "Al pie de un roble escarchado" probablemente sirvió de inspiración a nuestro autor para su drama:

\section{El renegado de Jerusalén ${ }^{69}$}

EF. ${ }^{71} \quad$ Entre los roncos suspiros de las ya desiertas alas salgan los triunfos más tristes y en cada suspiro un alma.

Que te casaste, enemiga, mas, ¿de qué me quejo?, ¡basta! Yo me casaré también por tomar de ti venganza, mas pues estás casada, celos te maten, pues con celos matas. ${ }^{72}$
"Al pie de un roble escarchado"70

[...] Hice a los desdenes guerra, guerra desdenes me hacen; maté a Belardo con celos, celos es bien que me maten.

No atendí siendo llamada, ahora no me oye nadie: con justa causa padezco: quien tal hace, que tal pague.

Desamé a Belardo un tiempo, $y$ el amor para vengarse quiere que le quiera agora y que él me olvide y desame. [...]

69. Renegado (f. $9 \mathrm{v}$ ).

70. Vega (Al pie de un roble escarchado, 257-259). Para un estudio de los rasgos métricos de este poema, $c f$. Llamas (2018: 82-85).

71. Por razones de economía espacial, abreviamos "Efrando" con "Ef.".

72. Aunque el estribillo, en la mayoría de parlamentos de Efrando, dice "pero si estás casada, / celos te maten, pues con celos matas", hemos seleccionado esta variación final — "mas pues estás casada, celos te maten, pues con celos matas"-, ya que, junto con los versos precedentes — particularmente el anterior, "por tomar de ti venganza"-, nos permite una mayor incidencia sobre los paralelismos existentes entre el largo pasaje de la comedia y el fragmento del romance lopesco presentado. Estos son notables también en el caso de Elisa, cuyos versos repetidos rezan "ya tiene enemigo fiero, / celos te maten, pues con celos muero". Si bien la composición del Fénix presenta el estribillo unimembre "quien tal hace, que tal pague", enfatizamos además los versos "Maté a Belardo con celos, / celos es bien que me maten" y "y el amor para vengarse" por la semejanza que mantienen con el tono y la temática de desamor y resarcimiento de las intervenciones del galán y su amada. 
Sánchez Jiménez, al estudiar la bucólica composición en su edición de los Romances de juventud del Monstruo de Naturaleza, apunta la posibilidad de que sea obra de un imitador, si bien se inclina por la hipótesis de la autoría lopesca. ${ }^{73}$ El autor de El renegado pudo acceder al texto fácilmente, dada la elevada cantidad de reimpresiones que tuvo el romance desde que vio la luz por primera vez en el Ramillete de flores. Quarta, quinta y sexta parte de flor de romances, editado en Lisboa en 1593 por Pedro Flores. Desde entonces, como recoge Suárez, el poema volvería a ser publicado, en época áurea, en 1594, 1595, 1596, 1597, 1600, 1602, 1604 y 1614. ${ }^{74}$ En el siglo xix, Durán lo recogió en su Romancero general o Colección de romances castellanos, y a partir del $\mathrm{xx}$ ha sido editado al menos otras siete veces.

En definitiva, teniendo en cuenta la notable difusión de "Al pie de un roble escarchado" junto con los paralelismos entre este y los versos introducidos en el primer acto de nuestra comedia — además de la presencia, al final de la segunda jornada, de otro fragmento de romance que, como el poema del Fénix, contiene un estribillo de un único verso- consideramos probable que nuestro poeta se inspirase en él para su Renegado. Nos encontraríamos, por tanto, ante un empleo del romance que amplía notablemente la capacidad referencial del drama para, aprovechando el conocimiento que sin duda el público de la época tenía de la obra de Lope, remitir a este y a su universo literario a través de un doble valor de intertextualidad. Con ello, nuestro escritor rendía un respetuoso homenaje al Monstruo de Naturaleza, incrementando, a su vez, el potencial estético de su propia comedia.

Por lo que respecta a fuentes de carácter histórico, es posible que el dramaturgo recurriese a la Arnoldi chronica Slavorum o Crónica eslava de Arnold, continuación de la Helmoldi chronica Slavorum o Crónica eslava de Helmold. Esta última recoge la historia de las tribus eslávicas o wendos hasta el año 1171 y fue prolongada hasta 1209 por el abad Arnold de Lübeck (¿?-1214) a lo largo de los siete libros que forman su Arnoldi chronica.

La razón por la cual un texto de temática eminentemente germánica incluye un apartado sobre la Tercera Cruzada, indica Loud en su reciente edición crítica de la relación de Arnold ${ }^{75}$ es el profundo impacto que esta tuvo en toda la cristiandad desde su desencadenante, la toma de Jerusalén, núcleo de los conflictos entre cristianos y musulmanes. La circunstancia de tratarse de un autor contemporáneo a los acontecimientos que nos ocupan otorga valor a su relato, pese a no tratarse de un testimonio en primera persona. La Arnoldi chronica Slavorum recoge en su Libro IV los sucesos relativos a la mencionada guerra y sus consecuencias remontándose a la época de Balduino IV. La narración del fallecimien-

73. Sánchez Jiménez (2015: 256).

74. Cf. Suárez (2015: 200).

75. Loud (2019: 17). 
to sin descendencia del joven monarca, de la muerte de su sobrino Balduino $\mathrm{V}$, del enfrentamiento de Raimundo de Trípoli con Guido de Lusignan y Sibila, y de las batallas de Seforia ${ }^{76}$ y Hattin se extiende entre los capítulos 2 y $4 .{ }^{.7}$ El número 1 recoge un sentido lamento del clérigo por la caída de Jerusalén en manos musulmanas y el 5 se refiere a las conquistas que Saladino realizó tras sus victorias en las contiendas recién señaladas.

El renegado de Jerusalén presenta algunas coincidencias con la crónica - matizadas por la medida en la que hay un fundamento propiamente histórico en la comedia y por el carácter teatral y ficcionalizador de esta-. Los aspectos más interesantes en lo tocante a esta cuestión atañen a Raimundo III de Trípoli. El drama se hace eco de su negativa a jurar fidelidad al nuevo rey de Jerusalén, lo cual también aparece en la obra de Arnold:

Después de ser confirmado como rey, Guido envió a los grandes hombres del reino la orden de que fuesen a rendirle homenaje y recibir beneficios reales de su mano. Entre ellos también envió este mensaje al Conde de Trípoli, puesto que al tener más dignidades que el resto, debería ser el primero en honrar al rey con sus acciones. Al escuchar lo que había sucedido, el conde se sorprendió, y respondió con asombro, diciendo: "El niño Balduino, que fue ungido como rey, ha muerto recientemente, y no he oído que haya [otro] rey [...]. Nadie puede hacerse a sí mismo rey, a menos que desee gobernar injustamente como un tirano [...]". Esto fue lo que provocó que el rey y el conde se pelearan durante un ańo y medio, y mostraran un gran rencor entre ellos. ${ }^{78}$

En El renegado de Jerusalén la resistencia del conde a rendir tributo al monarca se plasma como sigue:

Sibila. $\quad$ Muy bien el conde don Ramón pudiera venir a hacer lo mesmo, pues es justo, aunque lo impida su arrogancia fiera. Vuestro rey quiso ser, no fue mi gusto... ${ }^{79}$

Además, la inconformidad del antagonista de la fábula con la coronación de Guido queda más que patente en el siguiente parlamento suyo:

76. Este acontecimiento consistió en la aplastante derrota de un ejército de templarios y hospitalarios muy inferior numéricamente a las fuerzas de Saladino que tuvo lugar en Seforia dos meses antes de la victoria musulmana de Hattin. A la cabeza de los cristianos se encontraba Roger de Moulins, paladín que ostentaba el título de Gran Maestre de los Caballeros Hospitalarios y que falleció en la contienda.

77. Arnold (The Chronicle, 145-151).

78. Arnold (The Chronicle, 146-147). Traducción propia. Como vimos, sin embargo, no fue tal la duración de las hostilidades: la enemistad entre ambos nobles no duró sino unos ocho o nueve meses, desde agosto o septiembre de 1186 a mayo de 1187 (Loud 2019: 167-168, nota 29).

79. Renegado (f. 2 r). 


\begin{tabular}{|c|c|}
\hline RAMÓN. & \begin{tabular}{l}
\multicolumn{1}{c}{ Señor, } \\
pésame haberte ofendido, \\
pero pues sabes quién soy, \\
por mi sangre y por mi estado \\
rey que pude haber reinado \\
así como reinas hoy. \\
Y porque Sibila estuvo \\
terca de tomar mi mano, \\
aunque más terco el tirano \\
que me estorbó y la detuvo. ${ }^{80}$
\end{tabular} \\
\hline
\end{tabular}

Nuestro escritor, de haberse servido de la Arnoldi chronica Slavorum, habría escogido aquellos aspectos más coincidentes con la presentación negativa que pretendía proyectar del conde. El siguiente fragmento del relato histórico constituye un buen ejemplo de los elementos que el poeta, en una selección acorde con sus propios intereses dramáticos, habría aprovechado para configurar las ideas contenidas en su comedia:

Al oír esto, el Maestre de esta Orden, un hombre sabio y religioso llamado Roger, ${ }^{81}$ se presentó ante el conde y le dijo así: “¿Cómo puedes enorgullecerte del mal, tú, poderoso en la iniquidad? ¿Por qué conspiras contra el pueblo de Dios? Cuando fuiste engañado por tu afán por gobernar y juraste tu fe a Saladino, ilegalmente y en contra de la religión de Dios en el Cielo, te colocaste junto a Judas el traidor. Ahora, sigue mi consejo: reconcíliate con Dios, a quien has negado, y reconcíliate con el rey a quien has ofendido, no sea que lo que suceda en el futuro sea peor que lo que ha sucedido en el pasado". ${ }^{82}$

En tal filtro sobre la materia histórica, habitual en los dramas de tema fundamentalmente político de la época que nos ocupa, no tienen cabida las circunstancias que llevaron al conde de Trípoli a no reconocer al nuevo rey de Jerusalén y a retirarse a su feudo en Tiberíades, aspecto que, como hemos visto, Arnold documenta en su texto. Esta región sí es aludida en el Renegado bajo el apelativo de Tenebria:

$\begin{array}{ll}\text { Ramón. } & \text { No soy yo quien ser solía, } \\ \text { no, porque una ofensa muda, } \\ \text { otra forma es ya la mía. } \\ \text { [...] Yo no soy Ramón, no es mía, } \\ \text { por Tiberio así llamada, } \\ \text { la ciudad de Tenebria, } \\ \text { no sabe rendir mi espada } \\ \text { jenízaros de Turquía... }\end{array}$

80. Renegado (f. $5 \mathrm{v}$ ).

81. Arnold se refiere a Roger de Moulins, Gran Maestre de los Caballeros Hospitalarios.

82. Arnold (The Chronicle, 148).

83. Renegado (f. 7 r). 
Adicionalmente, los acontecimientos que condujeron a la Tercera Cruzada también se encuentran recogidos en De bello sacro continuatae historiae, libri VI, commentariis rerum Syriacarum Guilhelmi Tyrensis archiepiscopi, additi. Esta es una obra que Johannes Basilius Herold (1514-1561) escribió como continuación de la famosa e inconclusa crónica de Guillermo de Tiro (ca. 1130-1186) Belli sacri historia: libris XXIII comprehensa, de Hierosolyma, ac terra promissionis, adeoque universa pene Syria per Occidentalis principes Christianos recuperata: narrationis serie usque ad regnum Balduini quarti, per annos LXXXIIII continuata. ${ }^{84}$ Es destacable la existencia de una tirada conjunta de ambas relaciones en la cual cada una mantiene su propia portada y su paginación de modo independiente. En este volumen, la Belli sacri historia presenta todas las características que Huygens, en su correspondiente edición crítica, describió para la prínceps. ${ }^{85}$ Asimismo, comparte con la versión de De bello sacro continuatae historiae que le sucede en el tomo tanto lugar como fecha de impresión —-Basilea, 1549-, los cuales figuran en el colofón de la crónica del arzobispo tirio ${ }^{86}$ y en el prefacio ${ }^{87}$ de su continuación. El dato de su procedencia basiliense se recoge, además, en sus respectivas portadas, que también indican un editor en común entre sí, Philiberti Poyssenoti; sin embargo, la de Guillermo de Tiro muestra además el nombre de otro librero en su portada, Ioannem Oporinum, que no aparece en la de la crónica de Herold —aunque sí es mencionado en su preámbulo—. En esta tirada, otros tres breves textos, también en latín, suceden a los recién descritos: en primer lugar se encuentra un poema titulado Monachi acconensis episcopi de recuperata Ptolemaide liber, igualmente inserto en otras ediciones de De bello sacro continuatae historiae ${ }^{88}$ seguido de una De bello inter Hispanos et Sarracenos epistola y de una De albigensium haeresi extincta, epistola.

De bello sacro continuatae historiae concentra la narración de los conflictos entre los nobles francos de la Jerusalén de la época y sus sangrientas consecuencias, así como de parte de la dilatada trayectoria política y militar de Saladino,

84. Como señala Huygens en su edición crítica de la crónica, que él mismo optó por designar Chronique, nos es desconocido el modo en el cual el arzobispo de Tiro se refería a su propia obra. La mayoría de sus versiones manuscritas carecen de título, con la excepción de dos que portan la inscripción "Incipit historia rerum in partibus transmarinis gestarum a temporem successorum Mahumet usque ad annum domini M. C. LXXXIIII, edita a venerabili Willelmo Tyrensi archiepiscopo". Huygens no lo considera su título original. Otro par de textos contienen, precediendo al prólogo, lo siguiente: "Incipit prologus domini Guillelmi Tyrensis archiepiscopi in hystoriam Ierosolimitanam... Expliciunt libri de terra Ierosolimitana editi a venerabili viro Willelmo archiepiscopo Tyrensi”. Cf. Huygens (1986: 33). Esta circunstancia propicia que la crónica sea comúnmente designada como Historia rerum in partibus transmarinis gestarum y también como Historia Ierosomilitana.

85. Cf. Huygens (1986: 87-89).

86. Guillermo de Tiro (1549: 578). Al ser más conocido el autor por esta designación que por su apellido, la empleamos para referenciar su texto.

87. El prefacio de De bello sacro continuatae historiae carece de paginación.

88. Cf. Croke (1828: 92, nota 97). 
en sus dos primeros libros — concretamente, es el primero el que más interesaría a nuestro autor, puesto que la conflictiva coronación de Guido tras el fallecimiento de Balduino IV y Balduino $\mathrm{V}$ se encuentra a partir del tercero de sus diecinueve capítulos-. Estos dos libros señalados, junto con los otros cuatro que integran la relación, prolongan hasta 1521 la narración de acontecimientos desde el año en el cual finalizaba la crónica de Guillermo de Tiro. Esta última, por su parte, registra en veintitrés libros los hechos ocurridos en Jerusalén entre 1086 y $1184 .{ }^{89}$ Su pertinencia para nuestro drama comienza en el Libro Vigesimoprimero, donde el arzobispo refiere cómo el joven Balduino IV pasó a encontrarse bajo su tutela y cómo él mismo descubrió la afección del príncipe que, en última instancia, provocaría su temprano fallecimiento y, con él, las pugnas internas de la corte jerosolimitana.

En profunda conexión con la obra de Guillermo de Tiro recién comentada se encuentra la segunda propuesta de Spencer y Schevill como fuente de la comedia, la Conqueste d'Outremer. ${ }^{90}$ Se trata de un relato francés repleto de elementos fabulosos y novelescos con aportaciones del texto tirio traducido al castellano a mediados o finales del siglo XIII bajo el título La gran conquista de Ultramar. ${ }^{91}$ Algunos testimonios de esta traducción presentan atribución a Alfonso X; y otros, a Sancho IV, además de aquellos que no presentan datos al respecto.

La relación se ocupa de las Cruzadas arrancando con los antecedentes de la primera (1095-1099) y su convocatoria por el papa Urbano II. Estos acontecimientos son recogidos en el prólogo y los primeros veintinueve capítulos del Libro Primero, al cual siguen otros tres. Los hechos históricos que sirven de base a El renegado se encuentran entre los capítulos CXXVI y CXLV del Libro Cuarto. En ellos se comprende lo ocurrido entre el fallecimiento de Balduino $\mathrm{V}$ y la toma de Jerusalén por Saladino presentando un retrato más humanizado de Raimundo que el esbozado por otros autores. Así se aprecia en el ejemplo siguiente, correspondiente a la narración de la supuesta reacción del conde ante la petición de Saladino de acceder al reino de Jerusalén a través de Tiberíades:

Cuando el conde oyó aquel mandado de Norandin ${ }^{92}$ hobo ende muy grand pesar, é pensé que si dijiese de non d'aquello quel demandaba, que perdería consejo é ayuda de Saladin, en quien tenia gran ayuda é grand esperanza; é otrosí si otorgase aquello quel demandaba, que era su deshondra, é seria ende culpado é denostado por toda la cristiandad. ${ }^{93}$

89. Cabrera (2017: 6).

90. Spencer y Schevill (1937: 242).

91. Señala Gayangos (1951: VII) que el texto fuente principal, La conqueste d'Outremer, fue escrita en Roma en 1295 por el entonces obispo de Châlons, Gaston de Noailles.

92. Se trata de una referencia a un hijo de Saladino, Malec al-Afdal, también conocido como Nure-d-Din o Norandino, que heredó al morir su padre los reinos de Damasco, Jerusalén y Siria Baja, como indica Gayangos (1951: XV).

93. Ultramar (cap. CXXXII, Libro Cuarto). 


\section{Fechando la pieza: cuestiones políticas y textuales}

Spencer y Schevill, al acometer una posible datación para el drama, señalaban que podría ser posterior, no solo a 1609, sino también a 1619, año este último durante el cual vio la luz una reimpresión de la Jerusalén conquistada. ${ }^{94}$ Consideramos irrefutable que el texto se escribió después de 1609, teniendo en cuenta que la primera impresión del poema del Fénix, que sirvió de inspiración para escenas concretas de nuestra comedia, vio la luz en dicho año.

Una puesta en conexión de El renegado con su contexto conduce al ámbito de las relaciones internacionales, puesto que no arroja dudas respecto a su pertenencia, dentro del conjunto de dramas históricos, al subgrupo vinculado a la Historia extranjera. Su autor, en lugar de decantarse por la Segunda Cruzada, como hizo Lope en su composición aprovechando que esta permite exaltar aspectos y figuras patrióticas de la mano de personajes como Alfonso VII de León y Castilla o Ramón Berenguer IV de Barcelona, optó por el desastroso precedente de la tercera de estas campañas militares. La materia que aquí trata el escritor señala ineludiblemente en la dirección de Francia, ${ }^{95}$ referente de diversas menciones encomiásticas presentes en el texto. Muchas de ellas se introducen a través de Efrando, quien hace la siguiente advertencia a Saladino tras pedirle que libere a Elisa:

$\begin{array}{cl}\text { EFRANDO. } & {[\ldots] \text { porque si no me la das }} \\ \text { talaré tus campos verdes, } \\ \text { degollaré tus ganados, } \\ \text { pegaré fuego a tus mieses } \\ \text { entrarán hasta Damasco } \\ \text { los invencibles franceses } \\ \text { dando saco a vuestras casas, } \\ \text { forzando a vuestras mujeres. }{ }^{96}\end{array}$

Y poco antes del comienzo de la batalla de Hattin, el héroe enuncia el siguiente parlamento ensalzador de lo galo:

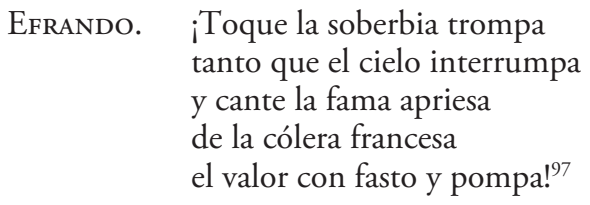

94. Spencer y Schevill (1937: 242).

95. Encontramos en El renegado una asociación entre franceses y francos que dota a los primeros de un trasfondo épico y defensor por excelencia de la cristiandad.

96. Renegado (f. 30v).

97. Renegado (f. 39v). 
De modo general, puede situarse el período de proximidad entre la Monarquía Hispánica y el Reino de Francia entre el asesinato del monarca galo Enrique IV, muerto en París en mayo de 1610, ${ }^{98}$ y el acceso de Richelieu al cargo de primer ministro en 1624, dado que el cardenal era percibido como un peligro para los intereses hispanos. ${ }^{99}$ Enrique IV, quien se había visto obligado a abjurar de su protestantismo para ser reconocido como rey, permitía la libertad de culto de los hugonotes en virtud del Edicto de Nantes (1598), algo que generaba un notable malestar en la corte española. Su sucesión por su esposa, María de Médici, cuya regencia se extendió entre 1610 y 1617 —hasta el acceso de Luis XIII al poder-, determinó un acercamiento entre Francia y España plasmado en el Tratado de Fontainebleau de 1611. Este incluía unas cláusulas matrimoniales que fijaban una doble unión dinástica y fueron firmadas en 1612 y ejecutadas en 1615 en Bidasoa. Así, se acordaba para un futuro mantenimiento de las relaciones pacíficas el matrimonio entre el futuro Luis XIII de Francia ${ }^{100}$ y Ana de Austria, por una parte; y, por otra, el casamiento de Felipe IV de España con Isabel de Francia, también conocida como Isabel de Borbón. El papel de Elisa en El renegado de Jerusalén, donde su presencia alcanza una relevancia muy superior a la de su hermana Sibila pese a que es esta última quien ocupa el trono en la época representada, responde a la circunstancia de que la figura de la infanta constituye una hábil referencia dirigida a la princesa gala. Este es un aspecto que la firma de Elisa en el folio en blanco que Ramón utiliza para privar a Efrando de su libertad viene a confirmar, puesto que su signatura reza, en lugar de Elisa de Jerusalén, Elisa de Borbón: ${ }^{101}$

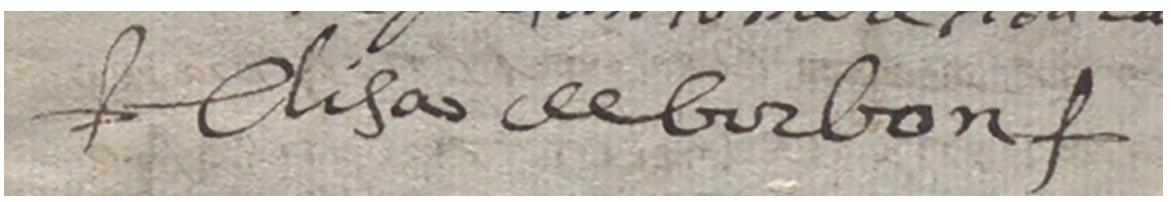

Figura 2: firma de Elisa “de Borbón” empleada por Ramón para su engaño.

Idéntica intención percibimos en la mención que realiza Saladino a la flor de lis para aludir, por medio de una metonimia, a la armada francesa. ${ }^{102}$ También Ferraguto, en su airado encuentro inicial con Guido, nombra dicho motivo herál-

98. Рейa (2003: 283).

99. $C f$. Elliott (2007: 166).

100. Pese a que ni el francés ni el español ocupaban aún el trono en el momento de la firma del tratado ni cuando contrajeron matrimonio, nos referimos a ellos, respectivamente, como Luis XIII y Felipe IV para una mayor claridad expositiva.

101. Cf. Renegado (ff. 40r).

102. "Sacar la lis que atrás yo puse en Francia / quiero, ...”, Renegado (f. 24r). 
dico con esta finalidad. ${ }^{103}$ Estos detalles nos proporcionan un punto de partida para nuestra horquilla temporal, que situaremos en el año de la firma de Fontainebleau, 1611. El período se acota al tomar en consideración un episodio que conllevó la reanudación de las hostilidades entre españoles y franceses antes, incluso, de la llegada al poder de Richelieu: nos referimos a la crisis sucesoria de los ducados de Mantua y Montferrato ${ }^{104}$ consecuencia de la muerte de Francisco II de Mantua en 1612, que determinó la ocupación forzosa de Montferrato por el entonces duque de Saboya, Carlos Manuel. Este, tras la firma del Tratado de Lyon (1601), venía mostrándose contrario a la presencia hispana en territorios italianos y proclive a una alianza con Francia para comprometer la integridad del Camino Español. Al duque de Saboya se enfrentaba Fernando de Gonzaga, duque de Mantua, apoyado por la Monarquía Hispánica. Aunque se logró una pausa temporal del conflicto a través de la Paz de Asti (1615), vista como deshonrosa para los intereses nacionales al adecuarse a los objetivos franceses, Carlos Manuel de Saboya volvió a la carga al ańo siguiente contando con apoyo galo - diez mil voluntarios a las órdenes del mariscal Lesdiguières-, holandés y veneciano. La Paz de Pavía, firmada en 1617 tras las victorias cosechadas en Aspi y Apertola y las conquistas de Vercelli, Salerio y Felizzano bajo las órdenes del gobernador español en Lombardía, Pedro de Toledo, ${ }^{105}$ supuso un revés para la imagen y las prioridades hispánicas, que, tras los triunfos cosechados, no se vieron debidamente satisfechas por un acuerdo que dejaba en una posición ventajosa al rebelde duque saboyano y, lo que es peor, al nuevo monarca francés, Luis XIII.

Podemos afirmar, pues, que 1616, cuando Francia prestó un apoyo considerable a Carlos Manuel de Saboya con la intención manifiesta de perjudicar a España, es un año durante el cual las probabilidades de composición de un texto tan claramente encomiástico de la nación gala se reducen notablemente. Nuestra propuesta para la escritura de El renegado de Jerusalén, por tanto, es el período entre 1611, cuando la doble unión matrimonial franco-hispana ya estaba concertada, y 1616.

Otro factor apoya esta hipótesis: nos referimos a la expulsión de los moriscos decretada por Felipe III en 1609, que se extendió entre dicho año y 1614. ${ }^{106}$ Quedaba así resuelta una problemática que había inquietado profundamente a Felipe II y que Reglá califica de "imperativo generacional” en uno de sus trabajos sobre la materia del cual extraemos esta interesante reflexión:

La motivación religiosa y sus reflejos en Ia estrategia mediterránea, implicada en una subversión peninsular —Turquía-Berbería-Andalucía-Aragón-Valenciaocupan un lugar destacado en las preocupaciones de Felipe II. Sin embargo, la idea

103. “¿O quieres marchitar las lises de oro / con el cierzo mortal de tu braveza?", Renegado (f. 11v).

104. Cf. Borreguero (2018: 129-132), Рейa (2003: 283-285).

105. Borreguero (2018: 131).

106. Elliott (2007: 312). 
de la expulsión de los moriscos, que llega a propugnar la famosa junta de Lisboa de 1582, no alcanza la madurez suficiente. Y cada fracaso de la política de asimilación es un acicate para reemprender el mismo camino con renovados esfuerzos. Por otra parte, Fernand Braudel ha tenido pleno acierto en situar la cuestión morisca en la dialéctica mediterránea entre los imperios hispano y otomano. El duque de Lerma, en una de las afirmaciones que encabezan este trabajo, dice: "para que todos estos reynos de Espańa queden tan puros y limpios desta gente como conviene". ${ }^{107}$

A través de su temática musulmana, El renegado de Jerusalén, procedente de unos años muy próximos al fallecimiento de Felipe II en los cuales, como se aprecia en las palabras de Reglá, las cuestiones más fundamentales de su reinado gozaban aún de actualidad, y más aún en lo tocante a lo islámico, vendría a suponer una hábil acción ideológica centrada en ensalzar la unión franco-española presentándola como un fuerte y heroico frente común ante el infiel. La pervivencia de la mentalidad xenófoba e intolerante de rechazo al morisco en la época en la que se fraguó su expulsión la describe Braudel como sigue:

Algunas espectaculares excepciones, en el plano religioso, o el hecho innegable de que los moriscos de las ciudades tendían a adoptar, cada vez más, el modo de vestir de los vencedores [cristianos], no pueden alterar el cuadro general. En Espańa se sabía muy bien que el corazón del morisco pertenecía a un inmenso universo que se extendía hasta la remota Persia, un universo poblado de casas iguales, donde imperaban costumbres análogas y creencias idénticas. Todas las diatribas antimoriscas de la época se resumen en esta declaración del cardenal de Toledo, "que estos son mahometanos como los de Argel". ${ }^{108}$

Esta reflexión resulta trascendental para, al menos, dos aspectos de nuestra comedia. De una parte, la referencia al vestido atañe a una cuestión específica relacionada con un personaje de gran importancia de El renegado: nos referimos a Galván, el musulmán que se convierte al cristianismo en la primera jornada. Se muestra al espectador por primera vez junto a Ferraguto cuando este compa-

107. Reglá (1964: 29). Para sus referencias a Braudel, cf. Braudel (2014: 180-214), donde el historiador francés analiza con su profundidad y lucidez habituales los choques político-sociales entre cristianos y musulmanes del siglo XVI — con sus ramificaciones desde siglos precedentes y hacia los comienzos del Xviı - poniendo en conexión, como bien señala Reglá, la rivalidad hispano-otomana con la fracasada asimilación cultural de los moriscos de la Península y su posterior expulsión. Sirva como ilustración esta reflexión inicial que el erudito francés plantea antes de acometer tan amplia labor: "No han faltado estos conflictos en el Mediterráneo del siglo xvi: el islam, por medio de sus mandatarios los turcos, se apoderó de las cristiandades de los Balcanes. Al oeste, la España de los Reyes Católicos se adueńó, con la conquista de Granada, del último reducto del islam ibérico. ¿Qué harán de sus conquistas los unos y los otros? En el este, los turcos se mantendrán en los Balcanes con unos cuantos hombres [...]. En el oeste, los españoles aplastarían sin piedad a sus súbditos musulmanes”, Braudel (2014: 181).

108. Braudel (2014: 207). 
rece en calidad de embajador ante Guido. ${ }^{109}$ Su parlamento inicial tiene la función de declarar sus intenciones de conversión: "Ahora falta mi embajada, Guido, / yo no vengo a enojarte; a ser cristiano vengo / de mis deseos persuadido". ${ }^{110}$ Cuando el público vuelve a verlo sobre las tablas, ya ha recibido el bautizo y se ha despojado de las vestimentas asociadas a su cultura, como indica la acotación correspondiente: "Entra Galván de cristiano". ${ }^{111}$ Sin embargo, no existe una contrapartida para este cambio de ropajes en el conde Ramón, pese a que también él abandona su fe y su bando: el texto no contiene ninguna instrucción que estipule que Ramón deba aparecer vestido de sarraceno, de modo análogo a como ocurre en el caso de Galván. Posiblemente su autor estimó, obedeciendo a sus conocimientos acerca de las preferencias del público y a los códigos sociales de la época, que mostrar a un renegado que asume hasta tal punto la identidad y las costumbres de la facción enemiga no era adecuado ni deseable. Por el contrario, presentar a un mahometano totalmente integrado en la cristiandad, con notable insistencia en su fervor y convicción en su nueva fe, resultaría un excelente modo de exponer los rasgos del morisco ideal, con una total interiorización del credo y los atributos culturales propios del cristianismo.

Siguiendo con las ideas expresadas por Reglá y Braudel, la asociación de moriscos y turcos a la que ambos hacen referencia encuentra su manifestación en el drama, repleto de referencias a Saladino y a sus súbditos como "turcos" y "jenízaros". El sultán no era de tal procedencia ni ascendencia, sino de origen kurdo. Su tensa relación con el gobernante selyúcida ${ }^{12}$ Nur al-Din y su aprovechamiento de la muerte de este para lograr más poder y territorios ponen de manifiesto que al ambicioso fundador de la dinastía ayubí le interesaba más mantener sus propios dominios ${ }^{113}$ que una relación particularmente próxima a los turco-persas, por más que en su ejército hubiese soldados de dicha extracción. Así pues, parece probable que el dramaturgo vinculase el bando enemigo de la época representada con el adversario de la Monarquía Hispánica en el Mediterráneo de su propio tiempo ciñéndose a la asociación mental entre turcos y moriscos común en sus años y en

109. Cf. Renegado (f. $11 \mathrm{v})$.

110. Renegado (f. 12v).

111. Renegado (f. 14v).

112. Con este término nos referimos a la sujeción de Nur al-Din al Sultanato Selyúcida, no a su pertenencia a la dinastía homónima. Dicho sultanato fue un imperio turco-persa a partir del cual surgiría, siglos después, el famoso Imperio Otomano. Sobre la vida de este importante líder islámico, $c f$. la nota 39 de este artículo.

113. La posición inicial de Saladino era la de vasallo de Nur al-Din. Fue su acumulación de poder lo que deterioró la relación entre ambos, dado que a este último le preocupaba tal circunstancia. La muerte de Nur al-Din permitió a Saladino continuar su ascenso político ahorrándole los costes de un combate entre ambos. Este fallecimiento le proporcionó una independencia que se tradujo en la conquista de Damasco, Hama, Doms y Siria —cuya ocupación completó en 1182 . Además, fue reconocido como sultán de Siria y Egipto por el califa al-Mustadí y fundó su propia dinastía, la ayubí. 
los precedentes. Esta asimilación de Saladino a la dinastía otomana se evidencia, además, en las referencias que Ferraguto, en su embajada con Guido, hace a Trebisonda y Laodicea, ${ }^{114}$ plazas que, siglos después del momento representado, se hallarían en manos otomanas, señalando que el rey debe entregárselas al sultán a cambio de no quebrar la tregua existente.

Como se aprecia al poner en relación el extracto de Braudel presentado más arriba con los aspectos que venimos exponiendo, los usos lingüísticos descritos pasan por una visión monolítica del islamismo que obviaba las disimilitudes entre los musulmanes procedentes de diversos lugares y culturas considerándolos habitantes de ese "universo poblado de casas iguales". ${ }^{115}$ En consecuencia, el empleo recurrente de los términos "turco" y "jenízaro" en el texto suma al alcance hispánico de referencia al morisco español una proyección universal. Sin perjuicio de la utilidad de tales designaciones como elementos de reafirmación ideológica, el autor de nuestra comedia probablemente no advertía diferencias sustanciales entre un musulmán como Saladino y un otomano, al igual que tampoco las percibiría entre un turco y un morisco de acuerdo con la mentalidad que venía configurándose desde antes del siglo xvi. ${ }^{116}$ Como indica Casillas, la coincidencia del fin de la Reconquista con la expansión otomana por el Meditarráneo y el este de Europa determinaron la entrada a escena de un paradigma entonces novedoso que perviviría en el teatro de siglos posteriores:

El arquetipo mahometano promovido por la Corona era la unión de una tradición medieval y de un nuevo enfoque que fusionaba a los berberiscos, a los turcos y a los moriscos, todos ellos opuestos a los intereses hispanos. El propio término "moro" testimoniaba esta evolución: de incluir en su significado únicamente a los habitantes de Mauritania empezó a ser utilizado para designar a todos los seguidores del Islam. ${ }^{117}$

\section{Renegados, moros y cristianos: entre la estética y la ideología}

Nos hemos referido en determinadas ocasiones a lo largo de este trabajo a El renegado de Jerusalén en calidad de drama histórico. En efecto, la pieza cumple con un

114. En el texto las localidades son denominadas "Trapisonda" y "Laudicia". El embajador también se refiere a "Papilia", si bien no podemos concretar a qué hace referencia esta expresión. $C f$. Renegado (f. 12r).

115. Braudel (2014: 207)

116. Mentalidad que también la paremiología documenta, como se aprecia en expresiones como “¡Guay de ti, Jerusalén, que te tienen moros!”, que el gramático Gonzalo Correas, que vivió entre los siglos XVI y XVII, recoge en su compilación de refranes y frases populares explicando que "moros llamaban en España a todos los mahometanos, aunque sean turcos". Cf. Correas (1924: 226). 117. Casillas (2014: 40-41). 
listado de características que elaboramos en otra investigación previa ${ }^{118}$ a partir de la bibliografía más relevante acerca de los rasgos más distintivos del drama histórico: ${ }^{119}$ sitúa la fábula en un marco histórico con personajes y acontecimientos de importancia decisiva en su trama, establece un diálogo intertemporal entre su época y la representada, recurre de modo verosímil a las unidades de tiempo y lugar, incluye una intriga amorosa que permite cierto alivio del contenido político, precisa de una escenografía compleja y cuidada y acoge los principios de decoro y, sobre todo, de justicia poética. No obstante, el texto también presenta motivos que remiten de modo ineludible a la denominada comedia de moros y cristianos. Se trata de referencias que, aunque no pasarían desapercibidas para el espectador áureo, no desdibujan el carácter de drama histórico-político de la obra. En relación con esta cuestión, afirma Carrasco Urgoiti que es frecuente que la estética de la comedia de moros y cristianos se subordine a diferente temática. ${ }^{120}$ Nos encontramos, pues, ante otro ejemplo de esta supeditación, nunca exenta de importantes implicaciones estéticas e ideológicas.

De modo muy general, puede decirse que la subcategoría que ahora nos ocupa está integrada por piezas que llevan a las tablas conflictos fronterizos estableciendo un límite significativo entre lo cristiano y lo islámico e incluyendo referentes orientados al ámbito de la Conquista musulmana de Hispania y/o la posterior Reconquista. ${ }^{121}$ Este conjunto de composiciones, por tanto, comparte con los dramas históricos la ubicación en un momento del pasado no necesariamente próximo. El renegado de Jerusalén, además de trascender el ámbito nacional, lleva a cabo un salto temporal particularmente amplio, si bien las circunstancias políticas que motivaron su escritura justifican esta traslación. Por otra parte, la interiorización de lo islámico en términos de otredad determina que "para simbolizar en una fiesta o representación la perpetua contienda, podía valer cualquier guerra de que tratase la Historia o la ficción", ${ }^{122}$ de modo que la presencia de motivos como los que estudiaremos a continuación bastaba y sobraba para que la audiencia áurea reconociese esa "perpetua contienda". En la confluencia de estas remisiones simbólicas codificadas de modo genérico al pasado hispánico con la escenificación de uno de los acontecimientos más relevantes de la historia del Reino Franco de Jerusalén se encuentra la clave interpretativa de nuestra comedia.

Podemos rastrear esa referencia genéricamente configurada al subgénero de moros y cristianos que hemos señalado en el patrón organizador de los acontecimientos que componen la diégesis, que frecuentemente contiene un desafío del musulmán al cristiano sucedido por el combate que desemboca en su subyu-

118. Cf. Sánchez Jiménez (2020: 125-140).

119. Cf. González Cañal (2017), Oleza (2013, 2012, 1986), Martínez Aguilar (2000), Spang (1998).

120. Carrasco Urgoiti (2002: 215).

121. Cf. Carrasco Urgoiti (2002: $214,1998: 365,1997: 489,491)$.

122. Carrasco Urgoiti (2003: 14). 
gación por parte de este último ${ }^{123}$ y en cuyo transcurso puede darse un acontecimiento milagroso que determine la espectacular derrota sarracena. ${ }^{124}$ En $E l$ renegado, este esquema de provocación y resarcimiento se manifiesta de un modo un tanto peculiar: quien reta no es un mahometano cualquiera, sino el conde Ramón, que recibe una caracterización moral inferior a la observable en el conjunto del bando sarraceno debido a su perjurio de la fe cristiana. El mero acto de negar a Dios, así como el secuestro de Elisa, constituyen por sí mismos una grave ofensa; sin embargo, hay un suceso definitivo a este respecto: el que cierra la segunda jornada. Efrando acude a la fortaleza de Saladino y, ante sus muros, reclama la liberación de la joven, a lo cual el conde da una insolente respuesta que constituye una inexcusable llamada al conflicto. ${ }^{125}$ Resulta elocuente la métrica de esta escena, escrita enteramente en romance, al igual que la narración del secuestro de la infanta en boca del agonizante Marcelo. En ambos pasajes se adivina el objetivo de rememorar la tradición romanceril fronteriza, que a menudo recogía la relación de sucesos relacionados con un cerco o un choque entre moros y cristianos. ${ }^{126}$ En este sentido, la presentación que de sí mismo hace Efrando ante sus oponentes constituye una excelente muestra de las emociones que el autor pretendía suscitar en su audiencia:

EFrando. $\begin{gathered}\text { Yo soy, } \\ \text { si no queréis conocerme, } \\ \text { el que pisó vuestras lunas, } \\ \text { el que os venció tantas veces; } \\ \text { yo soy aquel que en Arabia } \\ \text { escritos sus hechos tiene } \\ \text { con vuestra sangre por tinta } \\ \text { y los campos por papeles, } \\ \text { yo soy el que llaman Rayo, } \\ \text { mas no respeto las leyes, } \\ \text { y así de temor sus olas } \\ \text { suelen coronar sus sienes } \\ \text { las bocas del turbio Nilo; } \\ \text { los gastados huesos beben } \\ \text { a quien yo quité las vidas } \\ \text { y las carnes di a los peces. }{ }^{127}\end{gathered}$

Tras esta exaltada introducción, el caballero se dirige a Saladino para prevenirlo de la deslealtad de Ramón y advertirle que, si no deja marchar a Elisa,

123. Cf. Carrasco Urgoiti (2003: 37, 2002: 214), García Valdés (1998: 123).

124. Carrasco Urgoiti (1998: 365, 1997: 491-492), García Valdés (1998: 123).

125. Cf. Renegado (ff. $29 \mathrm{v}-31 \mathrm{r})$.

126. Cf. Carrasco Urgoiti (1989: 30-42).

127. Renegado (f. 30r). 
él y su nuevo aliado deberán afrontar las consecuencias. La respuesta del conde y los versos finales del acto no dejan lugar a dudas respecto a la cuestión del reto. Los reproducimos a continuación a fin de exponer cómo el estribillo unimembre se erige en recurso estético para incidir en la vileza e irreverencia de su antagonista:

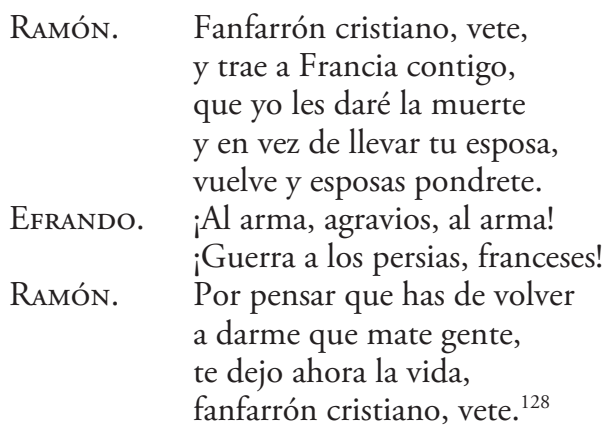

De esta manera, la obra establece unos referentes claros para el espectador de su época que podrían, incluso, trascender el ámbito de los mencionados romances. Considerando la notoria influencia del Fénix sobre nuestro texto, así como su gran representatividad dentro del subgénero que venimos estudiando —y su variante morisca—, ${ }^{129}$ además de la estrategia temática, referencial y dispositiva apreciable en el empleo de los romances en esta pieza, no resulta descabellada la posibilidad de que nuestro escritor, al dotar a su composición de las características de la comedia de moros y cristianos, no introdujese únicamente una evocación de la tradición romanceril relativa a este ámbito, sino que, además, dicha alusión constituyese, a su vez, un nuevo guiño a Lope.

Otros aspectos del drama que nos ocupa pueden ponerse en conexión con la estética propia de la comedia de moros y cristianos: tal es el caso de las prodigiosas apariciones del ángel y de la Muerte al final del combate, en el cual se adivina ya la victoria jerosolimitana. Estas tétricas figuras, si bien no modifican el resultado de la contienda, determinan que el conde no podrá escapar a su castigo, ${ }^{130}$ lo cual suma otra victoria cristiana a la conseguida en el campo de batalla. Asimismo, tras el fallecimiento de Ramón, también motivado por un elemento sobrenatural, Cartabón le corta la cabeza, motivo habitual en el género que representa, de modo particularmente violento y beligerante, el triunfo definitivo sobre el enemigo musulmán y el exterminio de este. ${ }^{131}$ Los

128. Renegado (ff. 30v-31r).

129. Cf. Ortega (2017), Grisel (2012), Carrasco Urgoiti (1971, 1982, 1989: 80-83, 1997, 1998, 2002: 214-215, 2003: 16-19).

130. Cf. Renegado (ff. $42 \mathrm{r}-43 \mathrm{v}$ ).

131. Ortega, en su tesis doctoral, repleta de ejemplos sobre las decapitaciones que suelen sufrir 
comentarios y mofas proferidas por el gracioso aportan un componente macabro a la escena:

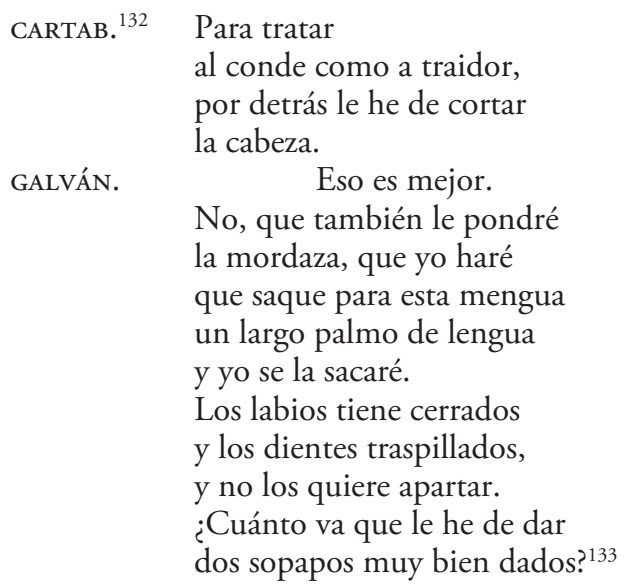

Tras decapitar a su antiguo amo, Cartabón se suma al resto de personajes presentes en el escenario - "Guido, Efrando, Elisa, Sibila y otros"-— ${ }^{134}$ portando en sus manos su cabeza cercenada, que sostiene hasta el final de la representación ${ }^{135}$ afirmando en tono jocoso que desea desquitarse de "todo lo que un tiempo calló" en la corte de Saladino. ${ }^{136}$ Las chanzas del donaire, combinadas con la brutalidad del tratamiento dado al cadáver, constituyen la máxima expresión de la derrota y la humillación del antagonista, sublimaciones de las constantes burlas que el criado dirige a la figura de Mahoma. ${ }^{137}$ Esto, sumado al conjunto de defectos atribuidos al conde, se traduce en la satisfacción y el aleccionamiento del público ante el que percibiría como un más que merecido final para él.

Por lo que respecta a los rasgos que integran la personalidad de Ramón en relación con el bando islámico del conflicto, podemos afirmar que de modo

los musulmanes en las comedias de moros y cristianos, afirma que "se trata de uno de los efectos especiales más populares del Siglo de Oro” (2017: 269). También ilustran esta cuestión Grisel (2012: 318-319), Carrasco Urgoiti (1998: 366, 2002: 214, 2003: 16) y García Valdés (1998: 136, nota 37 ).

132. Por razones de economía espacial, abreviamos "Cartabón” con "Cartab.”.

133. Renegado (f. 44r).

134. Cf. Renegado (f. 44r, acotación).

135. Cf. Renegado (ff. $44 \mathrm{v}-45 \mathrm{v}$ ).

136. Renegado (f. $45 \mathrm{v}$ ).

137. Sirvan las siguientes palabras del gracioso como ejemplo: "Señora, / el hablar me importa más / con esta canalla mora, / sepan todos cuantos son / de mahometano bando / que es Mahoma un bujarrón, / como lo está pregonando / el beato Cartabón; / sepan que fue un insolente / que comía alcuzcuz caliente...”. Cf. Renegado (ff. 28v-29r). 
general el personaje está construido de acuerdo con la imagen negativamente estereotipada que habitualmente se proyectaba de los primeros:

El moro no era visto —y sigo moviéndome fuera de los núcleos selectos— simplemente como un infiel, que se diferenciaba en su credo y ciertas normas de conducta. Dentro del contexto de un pasado común a los reinos de la Península, su papel se veía como el del agresor por excelencia. Pero el cristiano vencido reaccionó y triunfó. Este proceso se divulga en pliegos de romances y alusiones de predicadores; se ilustra mediante cuadros y retablos, y se ve representado en piezas dramáticas y en festejos, que tienen su faceta de rito, pues historia, hagiografía y política caminan juntas. ${ }^{138}$

Si el mahometano es el enemigo por excelencia, el otro por antonomasia, no debe sorprendernos su caracterización en las obras de ficción —al igual que en las de no ficción - con sombras que se oponen a las virtudes cristianas — concretamente, a las atribuidas a los héroes de la Reconquista-. Dicha configuración se evidencia en nuestro antagonista: Ramón es mentiroso, cruel, cobarde, irreverente ante las entidades superiores a él, envidioso, suspicaz y carente, en definitiva, de toda dignidad. Lo más importante, sin embargo, es su deslealtad, que lo lleva a renegar de su fe y de su rey, y que él mismo formula como sigue:

$\begin{array}{ll}\text { RAMóN. } & \text { Ahora verá el tirano } \\ \text { del honor y hacienda mía } \\ \text { que ser moro o ser cristiano } \\ \text { no estriba en valentía } \\ \text { si no es en mi pecho y mano. } \\ \text { Perdóname, patria avara, } \\ \text { puesto que te causé miedo } \\ \text { y en que soy cuervo repara, } \\ \text { que te he de sacar si puedo } \\ \text { los dos ojos de la cara, } \\ \text { y no te hagan mis enojos } \\ \text { por sinrazones y antojos, } \\ \text { que antes son justas y leyes, } \\ \text { pues son tus ojos tus reyes } \\ \text { y me ofendes con tus ojos. }{ }^{139}\end{array}$

Acerca de estos parlamentos, cabe destacar la escasa verosimilitud de un personaje que pregona orgulloso su propia perfidia. Esta peculiar forma de autorreferencialidad, no obstante, se encuentra regulada por las convenciones dramáticas áureas, que determinaban su validez. Así pues, Ramón manifiesta ser

138. Carrasco Urgoiti (1998: 363-364).

139. Renegado (ff. 39r-39v). 
consciente de encontrarse en el bando equivocado en parlamentos como el precedente cuyo propósito es conseguir en la audiencia la reafirmación de lo propio a través de la negación de lo ajeno. A esto se suma el espectacular final, que sin duda conmovería profundamente a un público ya impresionado tras la aparición de las temibles figuras del ángel y la Muerte. ${ }^{140}$ Tras intentar derrotarlas sin éxito, el conde se encuentra con Galván:

$\begin{array}{ll}\text { GaLVÁN. } & \begin{array}{l}\text { Pues no porque te desarmas } \\ \text { me piensas, perro, argüir, } \\ \text { que solo con estas armas } \\ \text { tengo esta vez de rendir. } \\ \text { (Saca una cruz del pecho.) } \\ \text { Ya sin la espada te embisto, } \\ \text { que no es de matar malquisto } \\ \text { una vida tan sin luz } \\ \text { con armas que tienen cruz, } \\ \text { pues en ellas murió Cristo. }\end{array} \\ \text { Ramón. } \quad \begin{array}{l}\text { Ya conmigo has acabado. } \\ \text { YaLVán. }\end{array} & \begin{array}{l}\text { Yo no te he muerto, infiel, } \\ \text { sino tu mismo pecado. }{ }^{141}\end{array}\end{array}$

El mensaje de la escena, al cual remite toda la pieza, es claro: Ramón se condena a sí mismo al renegar de Guido y de Dios, ${ }^{142}$ dado que la única relación posible entre cristianos y musulmanes es de enfrentamiento o de conversión por parte de estos últimos. La condena del antagonista es inevitable y se anticipa en numerosos parlamentos premonitorios en boca de distintos personajes que auguran su terrible final. ${ }^{143}$ Es notable en este sentido el determinismo que impregna toda la obra, particularmente perceptible en los parlamentos de Elisa, de los cuales el siguente constituye un buen ejemplo:

140. Cf. Renegado (ff. $42 \mathrm{r}-43 \mathrm{r}$ ).

141. Renegado (ff. 43r-43v).

142. El texto menciona el carácter a la vez humano y divino de Guido — Sibila, en un diálogo con su hermana, afima de su esposo "que es humano y es divino", Renegado (f. 3r). Asimismo, asistimos a una conversación entre Ramón y el monarca fruto de sus roces iniciales en la cual el primero señala: "Imagino / venganza en esto me pones, / que comerás corazones / por lo que tienes divino", y Guido responde: "por lo que tengo de humano, / no comeré del más bueno, / que puede tener veneno / el que parece más sano", Renegado (f. 6v). Este planteamiento remite a la idea de que pactar contra el rey de Jerusalén — lo cual, como hemos comprobado, fue lo único que el histórico Raimundo de Trípoli llevó a cabo- equivale a pactar contra la misma divinidad, tanto más grave al concertarse el acuerdo con los máximos enemigos de la cristiandad.

143. Presentamos a continuación otros parlamentos que auguran la suerte del conde. Guido (a Ramón): "Sol es el rey que da abrigo, / pero a su luz no os lleguéis, / que sois Ícaro y caeréis / al mar de vuestro castigo", Renegado (f. 6r); Galván (a Ramón): “...pues claro sé / por artículo de fe / que te vas a condenar, / y si contra los cristianos / tus pensamientos livianos / te vuelven como enemigo, / de parte de Dios te digo / que has de morir a mis manos", Renegado (f. 15r). 
ELISA. Falta otro golpe; Fortuna, dale a la rueda importuna. Mas, como te pintan varia, si a mí me has sido contraria desde la inocente curia ruego al cielo, renegado, que castigue tu pecado mas ya tú te castigaste, que puesto que a Dios negaste, tú propio te has castigado. ${ }^{144}$

La conversión a la religión enemiga no admite una visión objetiva en el ámbito de composición de El renegado de Jerusalén: solo resulta admisible cuando el tránsito se produce desde el islam al cristianismo; nunca en una dirección cuyo destino no sea este último. Por ello, a lo abominable del acto de Ramón, el autor opone lo extremadamente positivo del bautizo de Galván, quien, en última instancia, termina por asumir el papel heroico transformándose en amenaza para sus antiguos correligionarios como general del ejército jerosolimitano ${ }^{145} \mathrm{y}$ dando muerte al conde. En lo relativo a esta cuestión, baste señalar la incidencia del texto sobre el empleo del término "renegado" para designar de modo exclusivo a quienes se convierten al islam, como se aprecia en el siguiente parlamento que Galván dirige a su adversario pese a que, en términos imparciales, él mismo también podría recibir tal calificativo:

GaLván. Gran renegado has de ser, pero como a Dios le niegas, ingrato, el ser que te ha dado, y ya has de mirarle a ciegas, como en todo, renegado, de lo que hay en ti reniegas. ${ }^{146}$

Al igual que Galván, Saladino no manifiesta las múltiples y acusadas deficiencias presentes en su embajador, Ferraguto, y en el conde. Sus intenciones respecto al reino de Jerusalén, patentes en la ya comentada escena de la aparición de Norandino, y su exhibición de crueldad al empalar a Ferraguto, cuyo cadáver muestra a Ramón justo después de nombrarlo general de sus huestes, ${ }^{147}$ son los únicos rasgos censurables que encontramos en él. Por encima de estas faltas destacan sus sentimientos de amor, ternura y compasión hacia Elisa, que lo llevan al extremo de concederle la libertad y los medios para llegar segura hasta la presencia de los suyos.

144. Renegado (f. 34v).

145. Cf. Renegado (f. 40v).

146. Renegado (f. $15 \mathrm{v}$ ).

147. Cf. Renegado (ff. $37 \mathrm{v}-38 \mathrm{r}$ ). 
La construcción de la personalidad del sultán en los términos descritos remite al tipo conocido como moro cortés, caballeroso o sentimental, ${ }^{148}$ cuyo origen es rastreable, a través de diversas manifestaciones, hasta la fascinación que los cristianos experimentaban hacia la Granada musulmana y se vincula estrechamente con la maurofilia literaria. ${ }^{149} \mathrm{Si}$ bien la frontera con este reino resultó determinante en la conformación de la identidad castellana, la relación entre sus habitantes y los combatientes de la Reconquista no fue de constante enfrentamiento. El refinamiento estético nazarí no pasó desapercibido a los castellanos desarrollando en ellos un gusto por lo exótico que se plasmó en un elevado arquetipo poético de mahometano caballeresco - representante, sin embargo, de un universo que no por cautivador dejaba de ser percibido como decadente y, en consecuencia, debía ser combatido-, una suerte de réplica islámica del cristiano heroico y cortés que ocupó un lugar relevante en algunos romances fronterizos y protagonizó múltiples romances moriscos, ${ }^{150}$ además de cristalizar, en la segunda mitad del siglo XVI, en novelas moriscas tan influyentes como El Abencerraje y la hermosa Jarifa. Dichas obras narrativas suponen la culminación de esta idealización en una figura "que por siglos se mantuvo, renovándose continuamente como uno de los temas de la Literatura occidental"151 y que, en el teatro barroco, saltó a las tablas a través de la tendencia dramática que Carrasco Urgoiti denomina comedia morisca, que constituye "la última forma en que se vertió durante el Siglo de Oro la imagen estilizada de una caballeresca sociedad mora". ${ }^{152}$ La autora diferencia esta variante teatral de la comedia de moros y cristianos reservando este término para aquellas composiciones en las que adquiere centralidad el esquema de desafío, combate y derrota del musulmán por el héroe cristiano. ${ }^{153}$

En El renegado de Jerusalén se aprecia el propósito de evocar las dos variantes de la dramaturgia barroca comentadas. A través de Saladino y de Galván, se añaden a las remisiones a elementos formularios de la comedia de moros y cristianos que hemos analizado sutiles referencias al subgénero morisco como lo concibe Carrasco Urgoiti con efectos tanto estéticos como ideológicos. El sul-

148. Carrasco Urgoiti (1998: 364-365, 2002: 214-216, 2003: 16-17).

149. Belloni (2012: 37-39), Carrasco Urgoiti (1989: 21-30).

150. Cf. Belloni, (2012: 39), Carrasco Urgoiti, (1989: 40-42, 47-55).

151. Carrasco Urgoiti (1989: 30). Para una panorámica de la narrativa y la poesía épica moriscas de entre la segunda mitad del siglo xvi y comienzos del xviI, $c f$., de esta autora (Carrasco Urgoiti 1989: 55-77).

152. Carrasco Urgoiti (1982: 52). En términos muy similares se pronuncia la estudiosa en otros trabajos (cf. Carrasco Urgoiti 1997, 1998: 366-369, 2002: 215, 2003: 16-17). Para su recorrido detallado por la forma dramática morisca en tiempos anteriores y contemporáneos a Lope, $c f$. Carrasco Urgoiti (1989: 77-90).

153. Carrasco Urgoiti (1997: 489, 1998: 366-367, 2003: 17). Como la misma erudita demuestra en las obras referenciadas, comedia morisca y comedia de moros y cristianos eran frecuentemente cultivadas por los mismos dramaturgos, de lo cual Lope constituye un excelente ejemplo — aspecto que documenta en profundidad en su investigación de 1982_. 
tán, como vimos al ocuparnos de las modificaciones que la diégesis efectúa sobre los motivos históricos, a menudo fue descrito por las crónicas como un rey honorable y refinado, de modo que su imagen no necesitaba demasiadas alteraciones para encajar a la perfección con el paradigma de mahometano caballeroso recién descrito. Por otra parte, Galván, un personaje ficcional, está construido en clara correspondencia con este arquetipo pese a carecer de la profundidad del gobernante sarraceno, puesto que manifiesta desde su primera aparición en escena su propósito de bautizarse. Este acto es habitual en el moro cortés, quien opera movido por la convicción de que la suya es un "alma cristiana", ${ }^{154}$ y en el universo de El renegado se presenta como una victoria en contraposición al vencimiento sufrido por Ramón y por el bando musulmán, de lo cual se desprende la idea de que, mientras un bautismo siempre es un triunfo en términos absolutos, el proceso inverso es, asimismo, objetivamente pernicioso. Así, la fábula suma esta conversión a la variación introducida sobre el resultado de la batalla de Hattin y, desde la ficción, reescribe la Historia para sustituir el fracaso cruzado por un doble éxito reflejado en las dos únicas soluciones posibles ante el infiel: su cristianización o su eliminación.

Sobre el propósito artístico de la inclusión de ambas figuras prima la finalidad aleccionadora, que se orienta en dos direcciones: por un lado, la presencia de Galván permite mostrar al auditorio el ideal de la asimilación de los moriscos que, al no alcanzarse, dejó paso a su expulsión. Por otro, tanto este último como Saladino encarnan aspectos respetables dentro del bando mahometano en el cual ambos se encuentran al comienzo de la acción dramática: el primero, debido a su nueva fe; ${ }^{155}$ el segundo, en virtud de su posición social y ambos, en suma, a través de los rasgos que les adjudica el autor, constituyen el polo opuesto al de los otros dos personajes vinculados a la facción sarracena del universo de la obra, Ramón y Ferraguto, que quedan en una clara desventaja ética. Sin embargo, el embajador de Saladino se sitúa en una posición moral ligeramente superior a la del conde al disuadirlo de matar a Elisa, ${ }^{156}$ aunque finalmente su lascivia, su ambición y su falta de lealtad determinen su ejecución. ${ }^{157}$ En definitiva, el acto de renegar, que implica un tránsito voluntario a las filas del enemigo acérrimo de la cristiandad, un abandono de Dios sin redención posible, convierte a Ramón en un sujeto de otredad ante el cual no hay lugar para el respeto ni el entendimiento:

154. Carrasco Urgoiti (1998: 368, 2003: 17).

155. Cabría cuestionarse si, al abandonar la fe islámica e integrarse en la corte de Guido, puede considerarse a Galván parte de la esfera islámica de El renegado; sin embargo, es precisamente su posición inicial la que define las circunstancias de este personaje, razón por la cual procede clasificarlo como integrante de este ámbito, aunque con importantes matizaciones como las que aquí realizamos.

156. Cf. Renegado (f. 14v).

157. Cf. Renegado (ff. 35v-36v, 38r). 


\begin{tabular}{|c|c|}
\hline ALVÁN. & $\begin{array}{l}\text { El cielo, conde cruel, } \\
\text { hoy diferencia a los dos, } \\
\text { mi pecho y el tuyo, infiel, } \\
\text { pues, yo, moro, busco a Dios, } \\
\text { y tú, cristiano, huyes de él. } \\
\text { A donde estás pereció } \\
\text { por tu culpa, y pienso yo } \\
\text { que te ha querido dejar, } \\
\text { pues le vienes a negar } \\
\text { a donde él por ti murió. } \\
\text { Yo nací sin luz de fe, } \\
\text { y en el bautismo busqué } \\
\text { la luz que a tal Dios me guía, } \\
\text { y tú a negar a Turquía } \\
\text { te vas sin la luz que hallé. }\end{array}$ \\
\hline
\end{tabular}

Procedan de la comedia de moros y cristianos o de la morisca, podemos señalar que todos los elementos dramáticos analizados se orientan al reniego de Ramón, que da título a nuestra obra, y al castigo que recibe en consecuencia: el esquema de provocación, batalla y derrota y la presencia de Galván como moro caballeresco convergen en el fastuoso final donde son las propias fuerzas divinas las que terminan con la vida del conde y tiene lugar, no sin ironía, su decapitación. Esto nos conduce a la cuestión última de este trabajo: ¿cómo se relaciona el elogio de la alianza franco-española con el episodio histórico seleccionado y con los diversos motivos que hemos examinado?

La tarea de nuestro poeta no era en absoluto sencilla, puesto que debía presentar del modo más favorable posible el acercamiento a una nación que pocos años antes del momento de composición de El renegado de Jerusalén había permitido la libertad de culto a los hugonotes y que, históricamente, había rivalizado con España en múltiples ocasiones. Estas circunstancias imponían la necesidad de resaltar los aspectos positivos de Fontainebleau. Así, la comedia que nos ocupa enaltece la proximidad entre las naciones hispana y francesa, que prioriza sobre el enlace de Felipe IV con Isabel de Borbón. No obstante, esta última cuenta con una versión ficcional en el universo del drama, Elisa, cuya conexión con la histórica princesa queda en evidencia a través del detalle de su firma con el apellido de la descendiente de la dinastía que entonces gobernaba el país galo. De esta manera, su unión con el futuro rey español queda ingeniosamente referenciada.

La acción propagandística se dispone en torno a dos ejes fundamentales íntimamente interconectados: en primera instancia, era necesario transmitir el mensaje de que la Francia con la cual pactaba la Monarquía Hispánica era una que había desterrado definitivamente la herejía; por otra parte, se hacía preciso

158. Renegado (f. 14v). 
incidir en el pasado de ambos reinos como adalides de la fe cristiana. En lo tocante al primer aspecto, la ficcionalización llevada a cabo sobre el histórico Raimundo de Trípoli y su breve pacto con Saladino es fundamental: la presentación del conde Ramón como un detestable renegado, su espectacular lucha con la sombra y la Muerte, su sometimiento y su posterior decapitación remiten de forma metafórica al exterminio de todo aquello próximo a los principios de la Reforma en territorio galo, entendidos como una inadmisible heterodoxia. La traición que el antagonista lleva a cabo contra su propia fe en la obra se revela análoga a la perpetrada por la doctrina protestante contra Roma.

En segunda instancia, el aparato ideológico de nuestra pieza pone en contacto presente y pasado con la mirada puesta en el futuro que, teóricamente, aguardaba a las potencias francesa e hispana: un porvenir en el que ambas, codo con codo, trabajarían en la expansión de la verdadera y única fe. Para transmitir esta idea de una forma estéticamente eficaz, nuestro literato necesitaba conectar el Reino Franco de Jerusalén, baluarte de la cristiandad frente al enemigo musulmán, con el que los españoles percibían como el glorioso pasado de su propia nación, cuyo emblema fundamental era, precisamente, la lucha contra el infiel. El autor de El renegado realiza dicho engarce con tal pericia que no necesita mentar lo hispánico de modo explícito, pues es constantemente aludido mediante las tradiciones específicas evocadas a través de la mezcla genérica que hemos descrito: la alteración de los hechos convencionalmente aceptada para el drama histórico y los rasgos más definitorios de los textos pertenecientes a dicha categoría - esto es, la traslación cronológica a un tiempo pretérito con acontecimientos y personajes históricos decisivos en la trama, así como el establecimiento de un diálogo intertemporal entre la época representada y la propia de la composición - acogen en un todo cohesionado tanto rasgos arquetípicos de la comedia de moros y cristianos como elementos inherentes a la comedia morisca. De este modo, la representación concreta de Ramón y su muerte que el escritor dispone a través de los motivos que la audiencia barroca española tenía tan firmemente arraigados desde la tradición configuradora de su propia identidad, vinculada a la Reconquista, adquiere un sentido para dicho público que trasciende la mención a su propio pasado al darse en un momento en el cual el principal conflicto religioso que afectaba de modo fundamental a la Monarquía Hispánica era el que enfrentaba a Reforma y Contrarreforma — sin perjuicio de la rivalidad con los países islámicos, aún lejos de desaparecer-. A través de este solapamiento de distintos subgéneros dramáticos, el poeta pone en conexión la lucha cruzada contra el adversario mahometano, los conflictos entre cristianos y musulmanes por el dominio de la Península y las Baleares y, por último, el combate entre Reforma y Contrarreforma religiosas.

Al igual que la rivalidad con el islam había sido asumida como factor inherente a lo hispano, también la pugna con el protestantismo sería asimilada en el Barroco como rasgo distintivo de españolidad. El establecimiento de una continuidad, indentitariamente hablando, entre las constantes hostilidades con el 
mundo islámico y las guerras con los enemigos protestantes se presentaba, pues, como un paso lógico, como advertía Del Arco y Garay en su exhaustivo análisis de la representación de la sociedad hispánica en el teatro de Lope de Vega:

Una de las características esenciales del espańol de aquel tiempo es su profundo sentimiento religioso, heredado de la lucha encarnizada, durante más de ocho siglos, con los infieles. Como esta fe era exaltada, el catolicismo pudo, desde entonces, dirigir sin esfuerzo la actividad política y social. La Reforma avivó el sentimiento religioso. España había defendido la fe contra los moros; ahora quiso protegerla también contra los bárbaros europeos que osaban atacar la ortodoxia. Se consideraba como destinada a proteger la unidad católica, y llegó a ser el adversario más violento de la Reforma. ${ }^{159}$

El complejo entramado que hemos tenido ocasión de analizar concentra una amplia gama de referentes que, desde la Poesía y la Historia, transforman en triunfo de la cristiandad la histórica derrota cruzada frente a Saladino y conforman una comedia que adquiere su sentido único al ser puesto en relación con su ámbito de escritura, un breve lapso temporal durante el cual resultaba acertada y pertinente la representación de un texto tan francófilo como El renegado de Jerusalén. El autor glorifica y lleva a su propio tiempo los precedentes de la Tercera Cruzada para transformarlos en el preámbulo de la lucha contra los enemigos de la cristiandad que, teóricamente, uniría a franceses y españoles en esta particular composición que escapa a una concisa definición genérica, lo cual le dota de un elevado valor artístico-moralizante. Nuestro escritor supo imbricar con gran habilidad motivos propios de distintas subcategorías teatrales alcanzando el equilibrio entre la libertad creadora y la alusión a la realidad extratextual de su época. Poniendo en interacción el drama histórico con el subgénero de moros y cristianos y con la comedia morisca, la obra superpone una red de significados estéticos e ideológicos sobre los precedentes, personajes y transcurso de la batalla de Hattin, cuya representación se transforma en un encomio de la unión franco-hispánica cifrado en unos términos que remiten a lo más profundo de los elementos identitarios del pueblo español del Siglo de Oro. Esta estrategia, mediante el juego con lo racional y lo emocional de la audiencia, dota de gran eficacia a la presentación de la lucha contra la Reforma como prolongación natural del añejo conflicto entre cristianismo e islam y hace de El renegado de Jerusalén una sofisticada pieza histórico-política que sortea los conflictos entre las potencias española y francesa para incidir en los aspectos que habían propiciado un acercamiento como el que se había fraguado en sus respectivas cortes.

159. Arco y Garay (1941: 69). 


\section{Bibliografía}

Arata, Stefano, "La conquista de Jerusalén, Cervantes y la generación teatral de 1580", en Fausta Antonucci, Laura Arata, María del Valle Ojeda (eds.), Textos, géneros, temas. Investigaciones sobre el teatro del Siglo de Oro y su pervivencia, Pisa, Edizioni ETS, 2002a, pp. 34-126.

-, "Notas sobre la Conquista de Jerusalén y la transmisión manuscrita del primer teatro cervantino", en Fausta Antonucci, Laura Arata, María del Valle Ojeda (eds.), Textos, géneros, temas. Investigaciones sobre el teatro del Siglo de Oro y su pervivencia, Pisa, Edizioni ETS, 2002b, pp. 127-139.

Arco y Garay, Ricardo de, La sociedad española en las obras dramáticas de Lope de Vega, Madrid, s. n., 1941.

Arnold von Lübeck, The Chronicle of Arnold of Lübeck, ed. Graham A. Loud, Londres, Routledge, 2019, en línea, <https://play.google...=false>.

Barrera y Leirado, Cayetano Alberto de la, Catálogo bibliográfico y biográfico del teatro antiguo español: desde sus origenes hasta mediados del siglo XVIII, Madrid, Imprenta y Estereotipia de M. Rivadeneyra, 1860, en línea, <https:// play.google.com...\&rdot=1>.

Belloni, Benedetta, "La evolución de la figura del morisco en el teatro español del Siglo de Oro", en 'Scripta manent'. Actas del I Congreso Internacional Jóvenes Investigadores Siglo de Oro, JISO 2011, ed. Carlos Mata Induráin, Adrián J. Sáez, Pamplona, Servicio de Publicaciones de la Universidad de Navarra, 2012, pp. 35-46, en línea, <https://dadun.unav...2701>.

Borreguero Beltrán, Cristina, La Guerra de los Treinta años, 1618-1648: Europa ante el abismo, Madrid, La esfera de los libros, 2018.

Braudel, Fernand, El Mediterráneo y el mundo mediterráneo en la época de Felipe II, II, Ciudad de México, Fondo de Cultura Económica, 2014.

Brioso Santos, Héctor, "Introducción", en La conquista de Jerusalén por Godofre de Bullón, ed. Héctor Brioso Santos, Madrid, Cátedra, 2009, pp. 11-114.

Cabrera Ramos, María Isabel, Devastatio Constantinopolitana. La IV Cruzada, expugnación y transformaciones de la ciudad durante la ocupación latina (1204-1261), Granada, Universidad de Granada, 2017, en línea, <https:// digibug.ugr...cale-attribute $=$ fr $>$.

Carrasco Urgoiti, María Soledad, "El cerco de Santa Fe de Lope de Vega, ejemplo de comedia épica”, en Homenaje a William L. Fichter estudios sobre el teatro antiguo hispánico y otros ensayos, ed. A. David Kossoff y José Amor y Vázquez, Madrid, Castalia, 1971, pp. 115-125.

-, "Notas sobre el romance morisco y la comedia de Lope de Vega", Revista de filologia española, LXII, (1982), pp. 51-76, en línea, DOI: <https://doi. org/10.3989/rfe.1982.v62.i1/2.568>.

-, El moro de Granada en la literatura (Del siglo XV al XIX), Granada, Universidad de Granada, 1989.

—, "La frontera en la comedia de Lope de Vega", en Actas del Congreso La Fron- 
tera oriental nazarí como sujeto histórico (s. XIII-XVI): Lorca-Vera, 22 a 24 de noviembre de 1994, ed. Pedro Segura Artero, Almería, Instituto de Estudios Almerienses, 1997, pp. 489-499.

—, "Variantes de las Comedias de moros", en Actas del IV Congreso Internacional de la Asociación Internacional Siglo de Oro (AISO), (Alcalá de Henares, 22-27 de julio de 1996), ed. María Cruz García de Enterría y Alicia Cordón Mesa, Madrid, Universidad de Alcalá de Henares, 1998, pp. 363-369, en línea, <https://cvc.cervantes.es/...1_031.pdf>.

—, "Moros", en Diccionario de la comedia del Siglo de Oro, dir. Frank P. Casa, Luciano García Lorenzo, Germán Vega García-Luengos, Madrid, Castalia, 2002, pp. 213-216.

—, "Estudio introductorio", en El cerco del Peñón de Vélez, ed. C. George Peale y William R. Manson, Newark (Delaware), Juan de la Cuesta Hispanic Monographs, 2003, pp. 13-46.

Carreño, Antonio, "Introducción", en Obras completas de Lope de Vega. Poesía, 3: Jerusalén conquistada. Epopeya trágica, ed. Antonio Carreño, Madrid, Fundación José Antonio de Castro, 2003, pp. IX-XLII.

Casillas, Álvaro, Disfrazados de turcos: las fiestas de moros y cristianos en Denia y Lorca, Madrid, Universidad de Alcalá de Henares, 2014, en línea, <https:// studylib.es/doc/6628831/...turcos>.

Correas, Gonzalo, Vocabulario de refranes y frases proverbiales y otras fórmulas comunes de la lengua castellana en que van todos los impresos antes y otra gran copia que juntó el maestro González Correas, Madrid, Tipografía de la Revista de Archivos, Bibliotecas y Museos, 1924.

Cotarelo y Mori, Emilio, "Luis Vélez de Guevara y sus obras dramáticas", Boletín de la Real Academia Española, III (1916), pp. 621-652; IV (1917), pp. 137-171, 269-308, 414-444.

CROKe, Alexander, An essay on the origin, progress and decline of rhyming latin verse; with many specimens, Oxford, D. A. Talboys, 1828, en línea, <https:// books.google...AAJ>.

ElliotT, John Huxtable, España y su mundo, 1500-1700, Madrid, Taurus, 2007.

Ferrer Valls, Teresa, "Estudio introductorio", en El marqués del Vasto, ed. C. George Peale y William R. Manson, Newark (Delaware), Juan de la Cuesta Hispanic Monographs, 2008, pp. 13-31.

—, et al., "Pérez, Cristóbal", en Diccionario biográfico de actores del teatro clásico español (DICAT), dir. T. Ferrer Valls, Kassel, Reichenberger, 2008.

García Valdés, Celsa Carmen, "Comedias de moros y cristianos en el teatro de Tirso de Molina", en El ingenio cómico de Tirso de Molina: Actas del Congreso Internacional, Pamplona, Universidad de Navarra, 27-29 de abril de 1998, ed. Ignacio Arellano, Blanca Oteiza, Miguel Zugasti, Pamplona, Madrid, Instituto de Estudios Tirsianos, 1998, pp. 121-138, en línea, <https://dadun.unav.edu/handle/10171/38128>. 
Gayangos, Pascual de, "Introducción", en La gran conquista de Ultramar, ed. Pascual de Gayangos, Madrid, Atlas, 1951, pp. V-XVI.

González, Cristina, La tercera crónica de Alfonso X: La gran conquista de Ultramar, Londres, Tamesis Books, 1992.

González CaÑal, Rafael, "Introducción”, Cuadernos de Teatro clásico, núm. 32 (2017), pp. 11-24.

Greer, Margaret Rich, "Renegado (El) de Jerusalén”, Manos, dir. Margaret Rich Greer y Alejandro García-Reidy, 12/02/2021, en línea, <https://manos.net...renegado-el-de-jerusalen>.

Grisel Villegas Gerena, Miraida, "Personajes simbólicos en cuatro comedias de moros y cristianos de Lope de Vega", en El universo simbólico del poder en el Siglo de Oro, ed. Álvaro Baraibar Echeverría, Mariela Insúa Cereceda, Nueva York-Pamplona, Instituto de Estudios Auriseculares (IDEA), Servicio de Publicaciones de la Universidad de Navarra, 2012, pp. 315-330, en línea, <https://dadun.unav.edu/handle/10171/23081>.

Guillermo de Tiro, Belli sacri historia: libris XXIII comprehensa, de Hierosolyma, ac terra promissionis, adeoque universa pene Syria per Occidentalis principes Christianos recuperata: narrationis serie usque ad regnum Balduini quarti, per annos LXXXIIII continuata, ed. Philiberti Poyssenoti, Ioannem Oporinum, Basilea, 1549, en línea, <https://books.googl...esc=y>.

Herold, Johannes Basilius, "De bello sacro continuatae historiae, libri VI, commentariis rerum Syriacarum Guilhelmi Tyrensis archiepiscopi, additi”, en Belli sacri historia: libris XXIII comprehensa, de Hierosolyma, ac terra promissionis, adeoque universa pene Syria per Occidentalis principes Christianos recuperata: narrationis serie usque ad regnum Balduini quarti, per annos LXXXIIII continuata, ed. Philiberti Poyssenoti, Ioannem Oporinum, Basilea, 1549, en línea, <https://books.googl...esc=y>.

Hosler, John D, El sitio de acre 1189-1191: Saladino, Ricardo Corazon de León y la batalla que decidió la Tercera Cruzada, Barcelona, Edhasa, 2019.

Huygens, Robert Burchard Costantijn, "Introduction", en Chronique, I, ed. Robert B. C. Huygens, Hans E. Mayer y Gerhard Rösch, Turnhout, Brepols, 1986, pp. 1-95.

Llamas Martínez, Jacobo, "Los estribillos en los romances de juventud de Lope de Vega", Lectura y signo: revista de literatura, XIII (2018), pp. 69100, en línea, DOI: <http://dx.doi.org/10.18002/lys.v0i13.5669>.

Loud, Graham A., "Introduction", en The chronicle of Arnold of Lübeck, ed. Graham A. Loud, Londres, Routledge, 2019, pp. 17-52, en línea, <https:// play.google...=false>.

Martínez Aguilar, Miguel, "Convenciones genéricas de los dramas históricopolíticos del teatro áureo", Mágina. Revista Universitaria, núm. 8 (2000), pp. 57-72.

McKendrick, Melveena, Woman and Society in the Spanish Drama of the Golden Age: a Study of the "Mujer Varonil", Londres, Cambridge University Press, 1974. 
Medel del Castillo, Francisco, Índice general alfabético de todos los titulos de comedias que se han escrito por varios autores, antiguos, y modernos y de los Autos Sacramentales y alegóricos, assi de D. Pedro Calderón de la Barca, como de otros autores clásicos, Madrid, Imprenta de Alfonso de Mora, 1735, en línea, <http://www.cervantesvirtual...come/>.

MöHring, Hannes, Saladino: el sultán y su época 1138-1193, Valencia, Publicacions de la Universitat de València, 2010.

Oleza Simó, Joan, "La propuesta teatral del primer Lope de Vega”, en Teatro y prácticas escénicas. II: La comedia, ed. José Luis Carnet Vallés, Londres, Tamesis Books, 1986, pp. 251-308.

-, From Ancient Classical to Modern Classical. Lope de Vega and the New Challenges of Spanish Theater, Nueva York, Idea Books, 2012.

—, "Variaciones del drama historial en Lope de Vega", Anuario Lope de Vega. Texto, Literatura, Cultura, XIX (2013), pp. 150-187, en línea, DOI: <https:// doi.org/10.5565/rev/anuariolopedevega.71>.

Ortega Robles, Juan, Las comedias moriscas de Lope de Vega, Universidad de Castilla-La Mancha, 2017, en línea, <https://ruidera.uclm.es...Allowed=y>. Payne, Robert, La espada del Islam: una historia del mundo musulmán de Mahoma al Imperio otomano, Barcelona, Ático de los libros, 2019.

Paz y Meliá, Antonio, Catálogo de las piezas de teatro que se conservan en el Departamento de Manuscritos de la Biblioteca Nacional, Madrid, Imprenta del Colegio Nacional de Sordomudos, 1899, en línea, <https://archive.org...pi00bibl>.

-, Catálogo de las piezas de teatro que se conservan en el Departamento de Manuscritos de la Biblioteca Nacional, I, Madrid, Patronato de la Biblioteca Nacional, 1934, en línea, <http://www.cervantesvirtual.com/obra...mo-i--0/>.

Peña, Manuel, "La búsqueda de la paz y el 'remedio general", en Historia de España. Siglos XVI y XVII: la España de los Austrias, coord. Ricardo García Cárcel, Madrid, Cátedra, 2003, pp. 247-297.

Rank, Michael, Las Cruzadas y los Soldados de la Cruz, Five Minute Books, 2015, en línea, <https://books.google.e...redir_esc=y>.

Reglé, Joan, "La expulsión de los moriscos y sus consecuencias. Contribución a su estudio", en Estudios sobre los moriscos, ed. Joan Reglá, Valencia, Universidad de Valencia, 1964, pp. 24-135.

Renegado: El renegado de Jerusalén, Biblioteca Nacional de España, MSS/14.968, en línea, Biblioteca Digital Hispánica, <http://bdh-rd.bne. es/viewer.v...e $=1>$.

Rodríguez Campillo, M. José, María Dolores Jiménez López, y Gemma Bel EnGuix, "El disfraz varonil en el teatro español de los Siglos de Oro", Triangle: Language, Literature, Computation, núm. 4 (2011), pp. 69-85, en línea, DOI: <https://doi.org/10.17345/triangle4.69-85>.

SÁnchez Jiménez, Antonio (ed.), "12. Al pie de un roble escarchado", en Romances de juventud, ed. Antonio Sánchez Jiménez, Madrid, Cátedra, 2015, pp. 255-257, 259. 
SÁNCHez Jiménez, Raquel, Mundos históricos y mundos ficcionales en el teatro de Historia extranjera de Luis Vélez de Guevara, Valladolid, Universidad de Valladolid, 2020.

Schack, Adolf Fiedrich von, Historia de la Literatura y del Arte dramático en España, IV, Madrid, Imprenta y Fundición de M. Tello, 1887.

Spang, Kurt, "Apuntes para una definición del drama histórico", en El drama histórico. Teoría y comentarios, ed. Kurt Spang, Pamplona, EUNSA, 1998, pp. 11-50.

Spencer, Forrest Eugene, y Rudolph SCHEVILL, The Dramatic Works of Luis Vélez de Guevara. Their Plots, Sources and Bibliography, Berkeley, University of California Press, 1937, en línea, <http://www.cervantesvirt...phy/>.

Stroud, Mathew D., "The Resocialization of the Mujer Varonil in Three Plays by Vélez", en Antigüedad y Actualidad de Luis Vélez de Guevara: estudios críticos, ed. C. George Peale, Ámsterdam, Philadelphia, John Benjamins Publishing Company, 1983, pp. 111-126.

SuÁrez DíEz, José María, El romancero nuevo pastoril. Estudio y edición crítica (1589-1688), Madrid, Universidad Autónoma de Madrid, 2015, en línea, $<$ https://repositorio.uam.es...sequence $=1>$.

Ultramar: La gran conquista de Ultramar, Pascual de Gayangos (ed.), Madrid, Atlas, 1951.

Urzaiz Tortajada, Héctor, Catálogo de autores teatrales del siglo XVII, Madrid, Universidad Complutense, 2002, en línea, <http://www.cervantesvirtual... siglo-xvii/>.

Vega García-Luengos, Germán, Rosa Fernández Lera, y Andrés de Rey Sayagués, Ediciones de teatro español en la Biblioteca de Menéndez Pelayo (hasta 1833), II, Kassel, Edition Reichenberger, 2001, en línea, <http:// www.cervantesvirtual...1402-2978/>.

Vega, Lope de, Obras completas de Lope de Vega. Poesía, 3: Jerusalén conquistada. Epopeya trágica, ed. Antonio Carreño, Madrid, Fundación José Antonio de Castro, 2003.

—, "12. Al pie de un roble escarchado", en Romances de juventud, ed. Antonio Sánchez Jiménez, Madrid, Cátedra, 2015, pp. 257-259.

VITSE, Marc, "Apuntes para una síntesis contradictoria”, en La mujer en el teatro y la novela del siglo XVII. Actas del II coloquio del grupo de estudios sobre teatro español (GESTE), Toulouse, Institut d'Etudes Hispaniques et HispanoAmericaines, Université de Toulouse-Le Mirail, 1978, pp. 153-160. 